\title{
Effect of silica oxide nanoparticles on liver of adult male albino rat. Light and electron microscopic study
}

\author{
Original \\ Article \\ Shaimaa M. Fattin, Nevert Farid Abd ElSalam, Nevine Bahaa, Walaa Baher \\ Department of Histology \& Cell Biology, Faculty of Medicine, Ain Shams University, Cairo, \\ Egypt
}

\begin{abstract}
Introduction: Silica oxide nanoparticles ( $\left.\mathrm{SiO}_{2} \mathrm{NPs}\right)$ have a dominant medical role because of their fundamental characteristics. They have a wide range size (from 5 to $1000 \mathrm{~nm}$ ). They possess unique optical properties, high specific surface area, low density, adsorption capacity, capacity for encapsulation, and biocompatibility. These features led to their wide use in biomedical applications as catalyst supports, drug carriers, and gene delivery. However, little is known about their possible cytotoxic effects, especially with their wide biodistibution on different organs has been reported.

Aim of the work: To assess the effect of different doses and durations of intravenous injections of $\mathrm{SiO}_{2} \mathrm{NPs}_{\mathrm{s}}$ on the hepatic tissue structure of adult male albino rats.

Materials and Methods: Forty Wistar male adult albino rats were divided randomly into three groups. Group I; served as control group, group II; injected with $10 \mathrm{mg} / \mathrm{kg} \mathrm{SiO}{ }_{2} \mathrm{NPs}$ for two and four weeks and group III; injected with $30 \mathrm{mg} / \mathrm{kg}$ $\mathrm{SiO}_{2} \mathrm{NPs}$ for two and four weeks. All doses were given by intravenous injection in the tail vein. At the end of the experiment, liver of all rats was dissected out and processed for histological, immunohistochemical and ultrastructure study. Morphometric measurements and statistical analysis were also performed.

Results: $\mathrm{SiO}_{2} \mathrm{NPs}$ injections didn't affect the hepatic lobular organization in any dose or duration. However, they caused hepatocytes structural changes, hepatic granulomatous inflammatory reaction accompanied by localized fibrosis, being prominent with increasing $\mathrm{SiO}_{2} \mathrm{NPs}^{\prime}$ ' dose and duration of administration.

Conclusions and Recommendations: $\mathrm{SiO}_{2} \mathrm{NPs}$ could affect the liver even at small doses. This was augmented with increasing dose and duration of administration. More investigation must be done to fully elucidate the interplay between hepatocytes and other non-parenchymal hepatic cells.
\end{abstract}

Key Words: Ito cell, Kupffer cell, liver, Pit cell, Silica oxide nanoparticle ( $\left.\mathrm{SiO}_{2} \mathrm{NPs}\right)$

Revised: 23 June 2017, Accepted: 17 August 2017

Corresponding Author: Nevine Bahaa, Tel.: 0201003950080, E-mail: nevine_bahaaeldine@med.asu.edu.eg, Department of Histology and Cell Biology, Faculty of Medicine, Ain Shams University, Cairo, Egypt

ISSN: 1110-0559, September Vol. 40, No. 3

\section{INTRODUCTION}

Nanoparticles (NPs) are engineered compounds or ultrafine particles with size ranging between 1 and 100 nanometers ${ }^{[1]}$. Over 4000 years ago, ancient Egyptian used a recipe for black hair dye, which was shown to contain lead-sulphide nanocrystals of $5 \mathrm{~nm}$ diameter ${ }^{[2]}$.

Nanoparticles have unique physicochemical properties as regard to size, chemical composition, surface structure, solubility, shape and aggregation ${ }^{[3]}$. The large surface area to volume ratio of NPs led to an alteration in their biological activity compared to the parent bulk materials ${ }^{[4]}$. In the past two decades, the use of NPs in experimental and clinical settings had risen exponentially due to their wide range of biomedical applications, as in drug delivery, imaging and cell tracking ${ }^{[5]}$, and cancer therapy ${ }^{[6]}$.

Different forms of NPs actually exist, of which the metal oxide NPs were extensively used in applications as food, chemical material, and biological science ${ }^{[7]}$.
They were also introduced in cosmetics products and sunscreens ${ }^{[8]}$. Silica-based NPs, in particular, have received increasing interest due to their unique characteristics. They are fine type of NPs having a wide range size (generally from 5 to $1000 \mathrm{~nm}$ ), high specific surface area, low density and capacity for encapsulation. These features led to silica NPs being widely utilized as an inert solid supporting or entrapping matrix. They can be used as biosensors as they can be bound covalently with human serum albumin, and can also covalently immobilize hemoglobin ${ }^{[9]}$. The use of $\mathrm{SiO}_{2} \mathrm{NPs}$ included electronic applications ranging from microwave to optical devices ${ }^{[10]}$, fabrication of electric and thermal insulators ${ }^{[11]}$, gene delivery ${ }^{[12]}$, drug carriers ${ }^{[13]}$, and in medical imaging as magnetic resonance imaging $(\mathrm{MRI})^{[14]}$.

Although great pace has been made in the worldwide production and use of NPs, there is a serious lack of information about the impact of NPs on human health and environment, especially the potential for NP-induced 
toxicity ${ }^{[15]}$. Preliminary few reports of the toxicity of some NPs are available and indicate that they can affect biological behavior at the organ, tissue, cellular, subcellular, and protein levels. However, more fully understanding the basis of NP toxicity is a requisite to assess the occupational and environmental exposure risks, which must be overcome before NPs can be safely and efficiently applied in the field of medicine ${ }^{[16]}$.

Liver is the largest glandular tissue in the body, it plays an important role in the uptake, Storage, and distribution of both nutrients and vitamins from the bloodstream. In addition, liver degrades or conjugates numerous toxic substances and drugs, yet it can be damaged by such substances $^{[17]}$. Hence, the objectives of this study were to assess the effect of exposure of $\mathrm{SiO}_{2} \mathrm{NPs}$, in different doses and durations, on the hepatic structure of male adult albino rats using different histological, immunohistochemical and ultrastructure techniques.

\section{MATERIALS AND METHODS}

\section{Animals:}

Forty male adult Wister albino rats of average weight of 170 grams were purchased from the animal house of Medical Research Unit, Faculty of Medicine, Ain Shams University. They were housed in plastic cages with mesh wire covers and were given rat chow and water ad libitum at the animal house of Medical Research Unit, Faculty of Medicine, Ain Shams University. All animal procedures were performed in accordance with the general guide lines for the care and use of laboratory animals and approved by the animal ethical committee at Faculty of Medicine, Ain Shams University.

\section{Characterization of $\mathrm{SiO}_{2} \mathrm{NPs}$ :}

Silicon Dioxide Nanoparticles was purchased from NanoTech Egypt for Photo-Electronics, 6th of October city, Giza, Egypt, as white powder of size $\approx 5010 \pm \mathrm{nm}$. Characterization of $\mathrm{SiO}_{2} \mathrm{NPs}$ was done using transmission electron microscope (TEM) at the regional center for mycology and biotechnology, Al-Azhar University (JEOLJEM-1010), to evaluate their size, shape and aggregation state. This was done by grinding and diluting them in phosphate buffered saline (PBS) forming a suspension, which was deposited on carbon coated copper grids and allowed to dry at ambient temperature. Particles size of $\geq 100 \mathrm{SiO}_{2} \mathrm{NPs}$ were measured ${ }^{[18]}$ in different fields $(60000 \mathrm{X})$ using an ImageJ software package (US National Institutes of Health, Bethesda, Maryland, USA), installed on the TEM.

\section{Experimental design:}

The animals were randomly divided into three groups:

Group I (control group, $\mathrm{n}=20$ ); was equally subdivided into four subgroups.
- $\quad$ Subgroups IA and IB: were injected PBS into the tail vein, twice weekly for two weeks in a dose of $0.3 \mathrm{ml}$ and $0.9 \mathrm{ml}$ respectively.

- $\quad$ Subgroups IC and ID: were injected PBS for four weeks in same doses and route as subgroups IA and IB respectively.

Group II ( $\mathrm{n}=10)$ was equally subdivided into two subgroups.

- Subgroup IIA; received intravenous injection of $10 \mathrm{mg} \mathrm{SiO}{ }_{2} \mathrm{NPs} / \mathrm{kg}$ body weight ${ }^{[19]}$, suspended in $0.3 \mathrm{ml}$ PBS into the tail vein, twice a week for two weeks.

- Subgroup IIB; received intravenous injection of $10 \mathrm{mg} \mathrm{SiO}{ }_{2} \mathrm{NPs} / \mathrm{kg}$ body weight, suspended in $0.3 \mathrm{ml}$ PBS into the tail vein, twice a week for four weeks.

Group III ( $\mathrm{n}=10)$; was equally subdivided into two subgroups.

- Subgroup IIIA; received intravenous injection of $30 \mathrm{mg} \mathrm{SiO}{ }_{2} \mathrm{NPs} / \mathrm{kg}$ body weight ${ }^{[19]}$, suspended in $0.9 \mathrm{ml}$ PBS into the tail vein, twice a week for two weeks.

- Subgroup IIIB; received intravenous injection of $30 \mathrm{mg} \mathrm{SiO}{ }_{2} \mathrm{NPs} / \mathrm{kg}$ body weight, suspended in $0.9 \mathrm{ml}$ PBS into the tail vein, twice a week for four weeks.

The $\mathrm{SiO}_{2} \mathrm{NP}$ powder was grinded using a mortar, then suspended in PBS before intravenous injection into animals' tail veins.

\section{Sample collection and processing:}

The experimental animals were anesthetized with ether inhalation, and sacrificed two days after the last injection in each subgroup (either after two or four weeks). Laparotomy was done and the liver was dissected out. The right hepatic lobe was obtained and divided into two halves; one half was fixed in $10 \%$ neutral buffered formalin, and processed to obtain paraffin blocks. Sections of $5 \mu \mathrm{m}$-thickness were then subjected to H\&E and to indirect immuohistochemical staining using avidine-biotin peroxidase technique for demonstration of CD68 marker of macrophages ${ }^{[20]}$. The primary antibody was purchased from Sigma Aldrich, Germany as rabbit Monoclonal anti CD68 antibody (dilution 1:1000), product number: SAB5500070. Lung tissue was used as positive control sections, while negative controls were done after omitting the primary antibody.

The other half of right hepatic lobes was cut into $1 \mathrm{~mm} 3$ pieces and fixed in $1.5 \%$ glutaraldehyde to be further processed into epoxy resin-filled capsules. Semithin sections ( $1 \mu \mathrm{m}$ thick) were stained with toluidine blue and examined by the light microscope. Ultrathin sections (60-80 nm) were cut with a diamond knife, mounted on copper grids and contrasted with saturated uranyl acetate followed by lead citrate ${ }^{[2]}$ to be examined by TEM at the regional center for mycology and biotechnology, Al Azhar University (JEOL-JEM-1010). 


\section{Morphometric and statistical studies}

Samples were analyzed by using Leica DM2500 microscope (Leica microsystem, Heerburg, Switzerland) with built-in camera (Wetzlar, Germany). All images were digitally acquired using an image analyzer Leica $\mathrm{Q}$ win V.3 program (Wetzlar, Germany) installed on a computer in the Histology and Cell Biology department, Faculty of Medicine, Ain Shams University. Five different non overlapping fields from five different sections of different rats were examined in each group for measuring each of the following:

1- Number of CD68 positive cells in immunohistochemically stained sections (20X).

2- Number of inflammatory cellular aggregations in H\&E stained sections (10X).

3- Size of inflammatory cellular aggregates in H\&E stained sections (10X).

These data, in addition to the percentage of nanoparticle size measured in TEM (60000X) were collected as mean \pm SD. They were calculated, revised, and subjected to statistical analysis using SPSS.21 program (IBM Inc., Chicago, Illinois, USA). One-way analysis of variance (ANOVA) was performed, followed by post hoc least significance difference (LSD) for comparison between more than two groups. $\mathrm{P}$ value $\leq 0.05$ were considered statistically significant.

\section{RESULTS}

\section{Characterization of $\mathrm{SiO}_{2} \mathrm{NPS}$.}

Examination of NPs using TEM revealed tiny electron dense particles of relatively similar size range. They appeared nearly rounded, solid and non-porous (Fig. 1a). The $\mathrm{SiO}_{2} \mathrm{NPs}$ tended to coalesce together forming variable sized aggregates (Figs. $1 \mathrm{~b}$ inset). Mean size and percentage of nanoparticles was measured and illustrated in (Table $1 \&$ Histogram 1).

\section{Light microscopic results $H \& E$ stain:}

No structural differences were observed in all subgroups of the control animals of group (I).

The liver of control animals of group (I) liver appeared formed of hepatocytes arranged in hardly demarcated classic hepatic lobules with a centrally located vein and peripherally located portal tracts (Fig. 2a). In each lobule, the hepatocytes were arranged in branching and anastomosing cords radiating from the central vein to the periphery and separated by blood sinusoids. Each hepatocyte appeared as polygonal acidophilic cell having rounded central vesicular nucleus. Binucleated hepatocytes were also encountered (Fig. 2b). At the corners of the lobules, portal tracts were identified.
They were formed of stroma of connective tissue (CT) containing a bile ductule, a branch of hepatic artery, a branch of portal vein and a lymphatic vessel (Fig. 2c).

- In subgroup IIA (receiving $10 \mathrm{mg} \mathrm{SiO}_{2} \mathrm{NPs} / \mathrm{kg}$ for two weeks), the hepatic lobular organization was preserved, the structure of most of the hepatocytes of zone (III) around the central vein were comparable to the control group (Fig 3a). However, some hepatocytes of zone (I) surrounding the portal tracts mainly demonstrated variable sized cytoplasmic vacuolizations (Fig. 3b). Few aggregations of mononuclear cellular infiltrations were seen scattered either in-between hepatocytes (Fig. 3a) or near the portal areas (Fig. 3b). The aggregates' mean number was measured as $(2 \pm 1$, Histogram 1$)$. Their mean size was measured as $(257.48 \pm 0.6 \mu \mathrm{m}$, Histogram 1). Separation of few endothelial cells lining central veins were seen in some lobules (Fig. 3a). Congestion of portal venules was observed in some portal tracts (Fig.3b).

- In Subgroup IIB (receiving $10 \mathrm{mg} \mathrm{SiO}_{2} \mathrm{NPs} / \mathrm{kg}$ for four weeks), the general hepatic architecture was preserved, however, an apparent moderate structural alteration of the liver tissue was obviously seen which appeared focally scattered all through the liver sections. In zone (III) around the central vein, some vacuolated shrunken hepatocytes with deeply stained nuclei were present. Other few hepatocytes appeared with deeply acidophilic cytoplasm (Fig. 4a). Zone (I) around portal areas showed some hepatocytes with karyolytic nuclei and others appeared devoid of nuclei (Fig. 4b). Shrunken deeply acidophilic hepatocytes were seen surrounding mononuclear cellular aggregates (Fig. 4a inset). These aggregates were seen scattered inside the hepatic parenchyma (Fig. 4a inset) and in the periportal areas (Fig. 4b). They were significantly increased in number as compared to the control group and subgroup IIA, measuring ( $4 \pm 1)$, Histogram 1). However, they were significantly smaller in size than those in subgroup IIA, with a mean size measuring $(113.58 \pm 0.7 \mu \mathrm{m}$, Histogram 1). Few mononuclear cells were seen adherent to the central veins' endothelium. Many hepatic sinusoids appeared moderately dilated especially around central vein (Fig. 4a).

- In subgroup IIIA (receiving $30 \mathrm{mg} \mathrm{SiO}_{2} \mathrm{NPs} / \mathrm{kg}$ for two weeks), the architecture of classic hepatic lobules was also preserved. Few hepatocytes in zone III appeared shrunken with deeply acidophilic cytoplasm, others had karyolytic nuclei (Fig. 5a). Many hepatocytes in zone I around portal areas exhibited cytoplasmic vacuolizations (Fig. 5b). Multiple small, scattered mononuclear cellular aggregates were detected in the hepatic parenchyma (Figs. 5a, 5b). The aggregates were surrounded by a clear space separating them from the hepatocytes, especially in zone I (Fig. 5b). The number of the aggregates was significantly increased than subgroups IIA and IIB, measuring $(9 \pm 0.3)$ that was significantly 
increased as compared to those of subgroups IIA and IIB (Histogram I). Their size was significantly smaller as compared with those present in subgroups IIA in most sections especially in zone $\mathrm{I}$, measuring $(89.21 \pm 0.9 \mu \mathrm{m})$. However, this value was non-significantly decreased as compared to those of subgroup IIB (Histogram 1). Some mononuclear cellular aggregates showed accumulation of acidophilic hyaline material in-between their infiltrating cells. Dilated hepatic sinusoids appeared in all zones of the hepatic lobules (Figs. 5a, 5b).

- In subgroup IIIB (receiving $30 \mathrm{mg} \mathrm{SiO}_{2} \mathrm{NPs} / \mathrm{kg}$ for four weeks), most hepatocytes in zone III around the central veins exhibited granular cytoplasm, with rounded vesicular nuclei. Few of these hepatocytes showed karyolytic nuclei (Fig. 6a). Most hepatocytes of zone I around portal areas showed cytoplasmic vacuolization. Other few hepatocytes were seen disintegrated with illdefined borders. Some hepatocytes showed karyolytic or pyknotic nuclei. Numerous small mononuclear cellular aggregations were seen scattered in the hepatic parenchyma, each surrounded by a clear space (Fig. 6b). The number of the aggregates was significantly increased than those of subgroups IIA and IIB, measuring ( $7 \pm 0.2)$. However, this value was significantly decreased than those of subgroup IIIA (Histogram 1). Their mean size was measured as $(117.07 \pm 0.9 \mu \mathrm{m})$, that was significantly decreased than those of subgroups IIA, however, non-significantly increased as compared to subgroups IIB and IIIA (Histogram 1). Congested central veins were frequently seen with few mononuclear cells adherent to its endothelial lining (Fig. 6a). Congested dilated portal venules were also observed in focal areas (Fig. 6b). Mildly dilated blood sinusoids were mostly seen in-between the hepatocytes of zone I and III (Figs. 6a, 6b).

\section{Immunohistochemical stain:}

Few CD68 positive Kupffer cells were detected within the cells lining the blood sinusoids of the control group (Fig.7). Their mean number was measured as $(7 \pm 0.1$, Histogram 1).

In subgroup IIA, more CD68 positive Kupffer cells were detected in the sinusoidal lining, as compared to the control group. Positive reaction was also noticed in macrophages of the mononuclear cellular aggregations (Fig. 8a). The mean number of CD68 immunopositive cells was measured as $(21 \pm 0.5)$ that was significantly increased when compared to the control group (Histogram 1).

In subgroup IIB, an apparent increase in the number of CD68 positive Kupffer cells in the sinusoidal lining was noticed as compared to the control group and subgroup IIA. CD68 immunopositive cells were also detected in the inflammatory cellular aggregates and were comparable to those in subgroup IIA (Fig. $8 b)$. Statistically, the mean number of CD positive cells measured as $(26 \pm 1)$, that was significantly increased as compared to the control group. However, it was nonsignificantly increased when compared to subgroup IIA (Histogram 1).

- In subgroup IIIA, apparent increase in the CD68 positive Kupffer cells lining the blood sinusoids in comparison with the control group was demonstrated. However, they were comparable to those present in subgroup IIA and apparently decreased as compared to subgroup IIB. Macrophages within the inflammatory aggregates were also CD68 positive and their number was apparently comparable to subgroups IIA and IIB (Fig. 9a). A mean number of (20 \pm 0.7$)$ was detected, that was significantly increased as compared to the control group. However, this value was non-significantly increased when compared to subgroups IIA and IIB (Histogram 1).

- In subgroup IIIB, apparently increased immunoreactivity as compared to the control group was detected. However, it was comparable to subgroups IIA and IIIA, and apparently decreased when compared to subgroup IIB (Fig. 9b). A mean number of $(21 \pm 0.5)$ was detected, that was significantly increased as compared to the control group. However, it was non-significantly increased when compared to subgroups IIA IIB and IIIA (Histogram 1).

\section{Semithin sections:}

- In the control group, semithin sections showed cords of branching and anastomosing hepatocytes appearing polygonal with vesicular rounded nuclei. Blood sinusoids lined with endothelial cells were seen between the cords of hepatocytes (Fig. 10).

- Subgroup IIA examination showed some hepatocytes with cytoplasmic vacuolizations. Other hepatocytes had small deeply stained nuclei. Aggregation of mononuclear inflammatory cells in between the hepatocytes were clearly observed. The cells in the aggregates were mostly macrophages with their large oval or irregular nuclei. Few fibroblast-like cells with flattened nuclei and lymphocytes with deeply stained rounded nuclei were seen mainly at the periphery of the aggregates. Ito cells were seen containing many fat droplets (Fig. 11a).

- In subgroup IIB, most of the hepatocytes exhibited cytoplasmic vacuolizations. Some hepatocytes had small rounded vesicular nuclei. Multiple aggregations of mononuclear cells were seen containing mostly macrophages with irregular or kidney shaped nuclei. The center of the aggregate demonstrated structureless material. Apparently fewer numbers of mononuclear cells was seen in the inflammatory aggregate as compared to subgroup IIA (Fig. 11b).

- In subgroup IIIA, the hepatocytes appeared 
having numerous cytoplasmic fat droplets. Some hepatocytes appeared with small deeply stained pyknotic nuclei, while others had faintly-stained nuclei. Mononuclear cellular aggregations were seen in-between hepatocytes with predominance of macrophages with vesicular kidney shaped or oval nuclei. Fewer cell numbers within the inflammatory aggregates was apparently seen as compared to subgroups IIA and IIB (Fig. 12a).

In subgroup IIIB, most hepatocytes were filled with variable sized well circumscribed lipid droplets. Some hepatocytes exhibited nuclei with irregular outlines. Aggregations of mononuclear cellular infiltrations were observed scattered within the hepatic parenchyma. They were mainly formed of macrophages with large oval or kidney shaped nuclei, and lymphocytes with small rounded dense nuclei. Few fibroblast-like cells with flattened nuclei were also seen at the periphery of the aggregates. The central part of some aggregates was seen pale devoid of cells, and filled with structurless material (Fig. 12b).

\section{Transmission electron microscope results:}

- Examination by TEM in the control group showed hepatocytes having nuclei with regular outlines, prominent peripheral heterochromatin and prominent nucleolus. The cytoplasm showed regular rough endoplasmic reticulum (rER) surrounding the nucleus and many scattered mitochondria with apparent cristae. Multiple glycogen rosettes and few well circumscribed lipid globules were also seen. Endothelial cells with euchromatic nuclei were seen lining blood sinusoids (Fig. 13). Ito cells were seen in the space of Disse closely related to both; sinusoidal lining and parenchymal cells. Their cytoplasm exhibited characteristic cytoplasmic processes and many well circumscribed, electron lucent lipid droplets compressing their euchromatic nucleus at some sites (Fig. 14).

- In subgroup IIA, some electron dense cells with cytoplasmic processes, lipid droplets and electron dense nucleus were demonstrated in focal areas nearby aggregations of inflammatory cells in the hepatic parenchyma (Figs. 15, 16). The hepatocytes in the vicinity of these cells were seen with absent or small electron dense nuclei. Most of the hepatocytes exhibited either variable sized cytoplasmic electron lucent areas containing granular material (Fig. 15), or multiple lipid droplets (Figs. 15, 17). Numerous mitochondria were seen in the hepatocytes (Fig. 17). Most of the mitochondria showed electron dense particles in their matrix. These particles were also diffusely seen inside the hepatocytes cytoplasm (Fig.15 inset). Collagen fibers were seen deposited n-between cells of mononuclear inflammatory aggregations (Fig.16). Sinusoids were seen lined by endothelial cells with flattened nuclei and
Kupffer cells with irregular nuclei (Fig. 15). Pit cells were observed having few homogenously electron dense granules of relatively similar size, located mostly at one side of the nucleus. Pit cells appeared having their characteristic rod-cored vesicles containing straight rod structure bridging their entire diameter (Fig. 17).

- In subgroup IIB, many hepatocytes having variablesized electron dense mitochondria with unapparent cristae were detected. Confluent cytoplasmic electron lucent areas containing homogenous material of medium electron density were noticed in most of the hepatocytes. Abundant cytoplasmic lipid droplets were also observed (Fig. 18). Collagen fibers were seen deposited around Ito cells (Fig. 18) and in the hepatic parenchyma (Fig. 19). Collagen fibrils were also seen in-between aggregations of mononuclear inflammatory cells (Fig. 20). Pit cells were also seen in the sinusoidal lumen having short cytoplasmic processes, with cytoplasmic dense granules and characteristic rod-cored vesicles (Fig. 19).

- In subgroup IIIA, some hepatocytes appeared with irregular euchromatic nuclei (Fig. 21), while others exhibited hyperchromatic small irregular nuclei (Fig. 22). Numerous mitochondria with apparent cristae were grouped together in the hepatocytes cytoplasm (Figs. 21, 22). Diffuse small electron dense granular deposits were noticed inside the cytoplasm of hepatocytes (Figs. 22, 23) and in the space of Disse (Fig. 22). Oval cells were seen in some sections nearby portal areas (Fig. 22), or adjacent to aggregations of mononuclear cells (Fig. 23). They were well recognized by their large euchromatic nuclei with scanty peripheral chromatin and little electron lucent cytoplasm with few organelles. Kupffer cells were observed with multiple phagocytic vacuoles (Fig. 21). Collagen fibers were seen deposited nearby Ito cells (Fig. 21) or myofibroblast (Fig. 22) and inbetween cells of mononuclear inflammatory aggregations (Fig. 23).

- In group IIIB, most of the hepatocytes showed cytoplasmic wide electron lucent irregular areas, filled with electron lucent granular material (Fig. 24). Enormous number of small electron dense particles appeared in hepatocytes' cytoplasm inbetween mitochondria. The mitochondria in most of hepatocytes were seen aggregated together in groups, exhibiting scattered electron dense matrix particles (Figs. 24, 25, 26). The nuclei of most of the hepatocytes appeared rounded and euchromatic (Figs. 25, 26). Collagen fibers were noticed adjacent to Ito cells that contained multiple lipid droplets (Fig. 24). Large Kupffer cells were seen containing multiple heterolysosomes (Fig. 26). Pit cells were also observed with their cytoplasmic dense granules. Spindle shaped myofibroblasts were recognized with their elongated electron lucent nuclei and spindle shaped cytoplasmic processes (Fig. 27). 
Table 1: Mean size and percentage of Nanoparticles:

\begin{tabular}{|c|c|c|c|c|c|c|}
\hline $\mathrm{Siz}$ & $<40 \mathrm{~nm}$ & $40-45 \mathrm{~nm}$ & $45-50 \mathrm{~nm}$ & $50-55 \mathrm{~nm}$ & $55-60 \mathrm{~nm}$ & $>60 \mathrm{~nm}$ \\
\hline Percentage & $6 \%$ & $14 \%$ & $20 \%$ & $30 \%$ & $14 \%$ & $16 \%$ \\
\hline
\end{tabular}

Histogram (1): Mean values of the nanoparticles size, number of CD68 positive cells, number and size of mononuclear cellular aggregates.

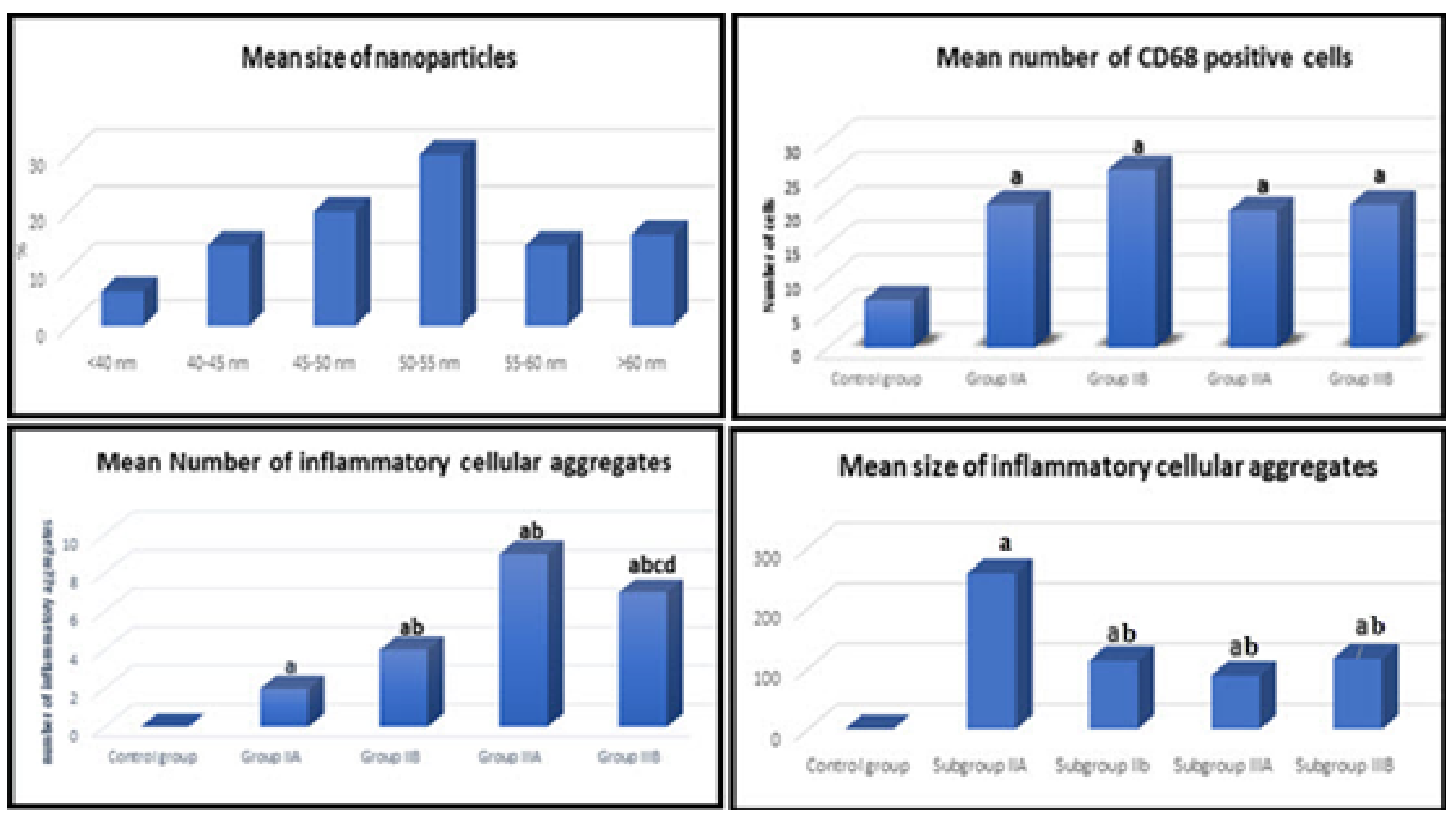

a: Significance calculated by least significant difference (LSD) at $\mathrm{P}<0.05$ from the control group (I).

b: Significance calculated by LSD at $\mathrm{P}<0.05$ from subgroup (IIA).

c: Significance calculated by LSD at $\mathrm{P}<0.05$ from group (IIB).

d: Significance calculated by LSD at $\mathrm{P}<0.05$ from group (IIIA)

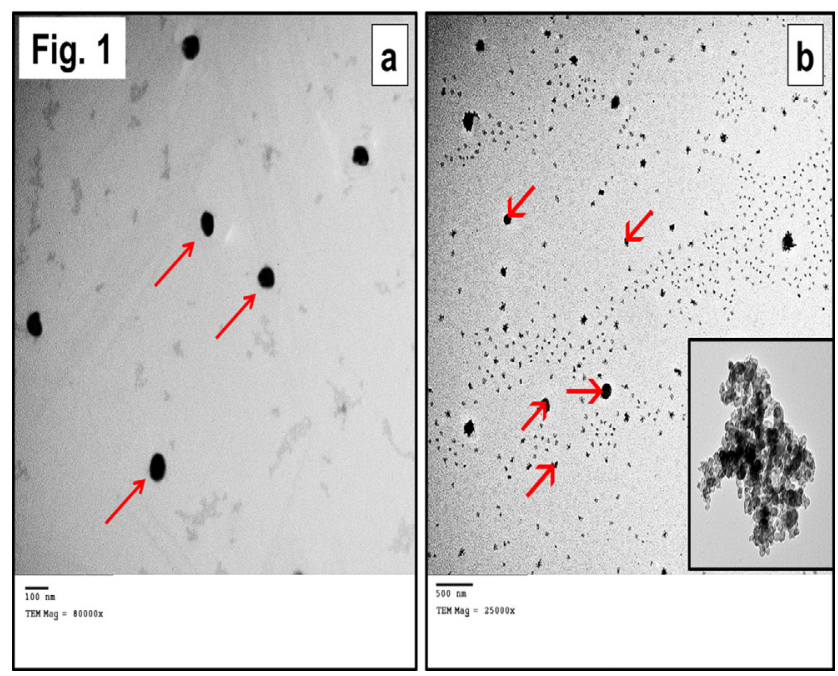

Fig. 1: A TEM of $\mathrm{SiO}_{2} \mathrm{NPS}_{\mathrm{S}}$ showing (1a): non-porous rounded, electron dense particles $(\uparrow)$. (1b): variable sized nanoparticle aggregations $(\uparrow)$, Inset shows a higher magnification of a NP aggregate.

(TEM, Ia x 80000, Ib x 25000, inset x 50000).

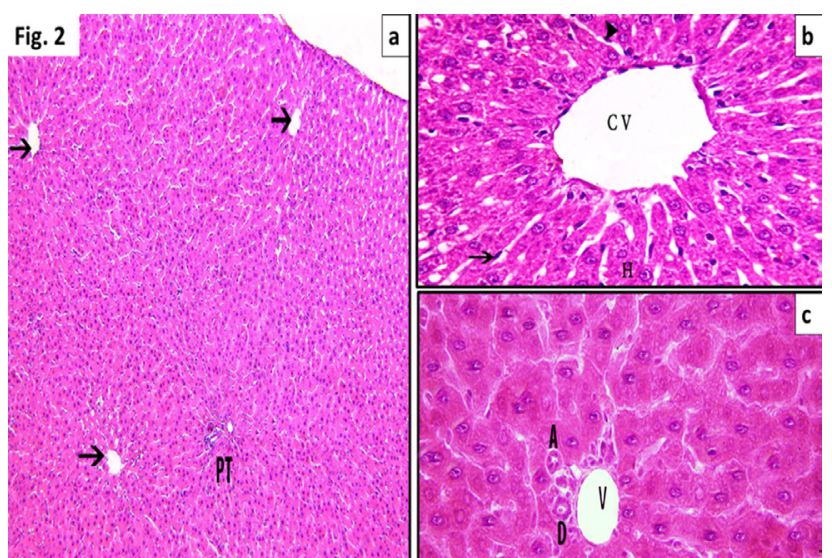

Fig. 2: Group I showing (2a): classic hepatic lobule with illdefined boundaries. Central veins $(\uparrow)$ and a portal tract $(\mathrm{PT})$ are seen. $(2 \mathrm{~b})$ : Hepatocytes $(\mathrm{H})$ with vesicular nuclei and acidophilic cytoplasm arranged in anastomosing cords around a central vein $(\mathrm{CV})$. Blood sinusoids are seen in-between hepatocytes cords lined with endothelial cells $(\uparrow)$. Notice the binucleated hepatocytes $(\triangleright)$. (2c): Portal tract containing a branch of hepatic artery (A), portal venule (V) and bile ductule (D).

(H\&E, 2a x100, 2b, 2c x 400). 


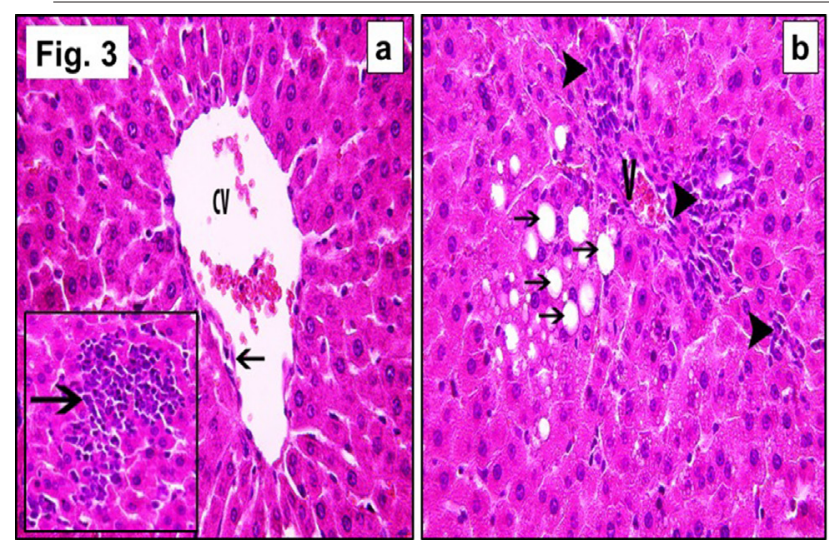

Fig. 3: Subgroup IIA showing, (3a): a central vein (CV) with partially separated endothelial cells $(\uparrow)$. The inset shows aggregation of mononuclear cells in-between hepatocytes $(\uparrow)$. (3b): showing periportal mononuclear cellular infiltration $(-)$ and congested portal venule (V). Many hepatocytes show variable sized vacuoles $(\uparrow)$. (H\&E; x 400, inset x 400).
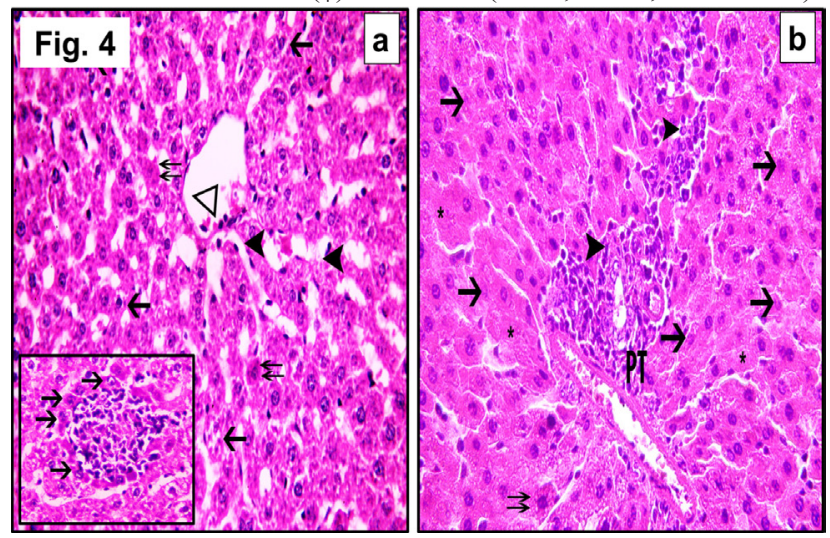

Fig. 4: Subgroup IIB showing, (4a): some hepatocytes with vacuolated shrunken deeply stained nuclei $(\uparrow)$ while other few hepatocytes appear with deeply acidophilic cytoplasm $(\uparrow \uparrow)$. Notice many dilated blood sinusoids in zone III $(\boldsymbol{\Delta})$. Few nonnuclear cells can be seen adherent to the central vein's endothelium $(\Delta)$. Inset shows large aggregation of mononuclear cells in the hepatic parenchyma surrounded by shrunken deeply acidophilic hepatocytes ( $\uparrow$ ). (4b): Portal tract (PT) with aggregation of mononuclear cells $(\boldsymbol{\Lambda})$. Notice hepatocytes with karyolytic $(\uparrow)$, deeply stained $(\uparrow \uparrow)$ nuclei. Some hepatocytes can be seen devoid of nuclei $(*)$

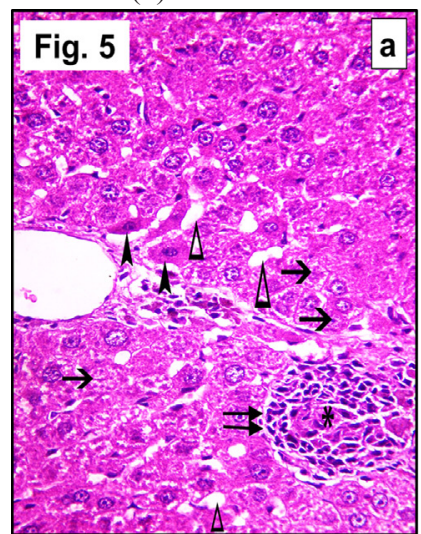
(H\&E x 400, inset x 400).

Fig. 5: Subgroup IIIA showing, (5a): few hepatocytes with deeply acidophilic cytoplasm $(\boldsymbol{\Lambda})$. Karyolytic nuclei $(\uparrow)$ can be seen in few hepatocytes. Acidophilic material (*) is observed within the mononuclear cellular aggregate $(\uparrow \uparrow)$. Notice the dilated hepatic sinusoids $(\Delta)$. (5b): hepatocytes in the portal area with vacuolated cytoplasm $(\boldsymbol{\Lambda})$. Mononuclear cellular aggregates surrounded by a clear space $(\uparrow \uparrow)$ and dilated blood sinusoids $(\uparrow)$ can be seen.

$(H \& E$ x 400).

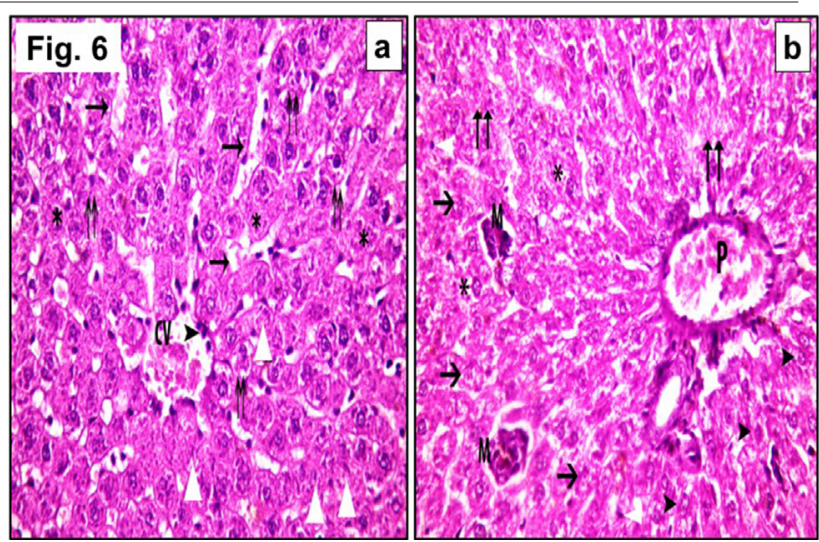

Fig. 6: Subgroup IIIB showing, (6a): All hepatocytes with granular cytoplasm $(*)$. Few hepatocytes can be noticed with karyolytic nuclei (white $\Delta$ ). Congestion of central vein $(\mathrm{CV})$ can be seen, with few mononuclear cells adherent to its endothelial lining $(\boldsymbol{\Delta})$ Dilated blood sinusoids can be observed ( $\uparrow$ ). (6b): Periportal area showing disintegrated hepatocytes with ill-defined boundaries $(\uparrow \uparrow)$. Notice many hepatocytes with cytoplasmic vacuolization $(*)$ Karyolytic $(\uparrow)$ or pyknotic (white $\Delta$ ) nuclei are seen. Congested dilated portal venule can be seen (P). Small mononuclear cellular aggregates are clearly observed surrounded by a clear space (M).

$(\mathrm{H} \& \mathrm{E} \times \mathrm{400})$

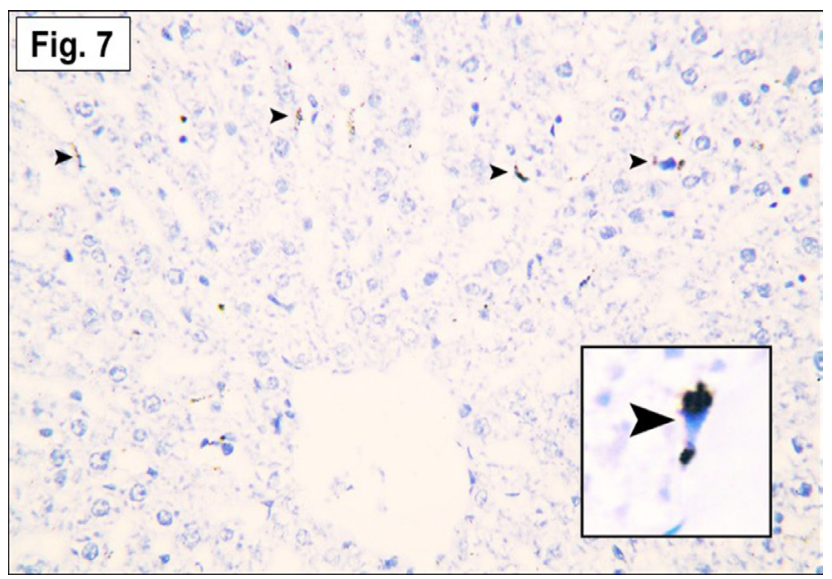

Fig. 7: Control group showing positive immunoreactivity of CD 68 antibody in few Kupffer cells $(\boldsymbol{\Delta})$.

(Avidine-biotin peroxidase technique $\mathrm{x} 400$, inset $\mathrm{x} 1000$ ).

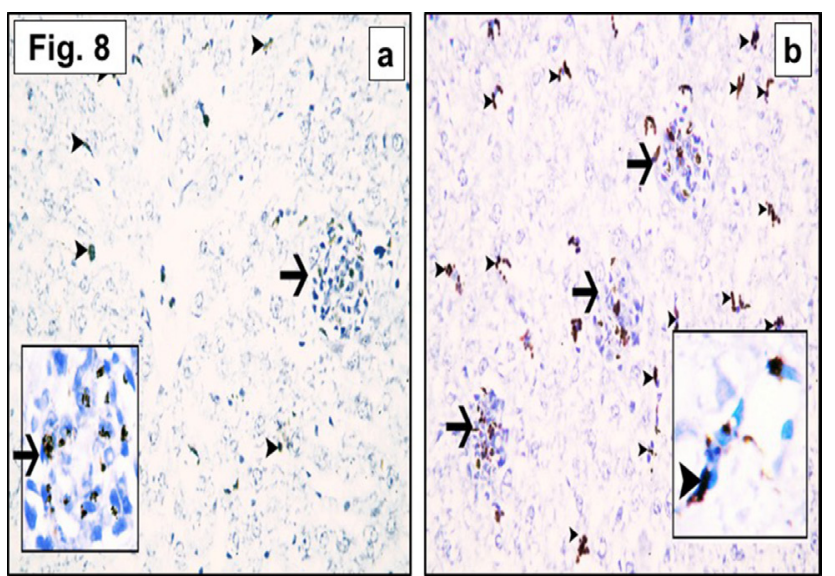

Fig. 8: In (8a): Subgroup IIA; showing many CD68 positive Kupffer cells lining the sinusoids $(\boldsymbol{\Lambda})$. Positive immunoreaction is also seen in the macrophages of mononuclear cellular aggregate ( $\uparrow)$. (8b): Subgroup IIB; showing numerous CD68 positive Kupffer cells lining the hepatic sinusoids $(\boldsymbol{\Delta})$. Notice the immunopositive reaction in macrophages inside the inflammatory cellular aggregations $(\uparrow)$ (Avidine-Biotin peroxidase technique x400, insets x 1000). 


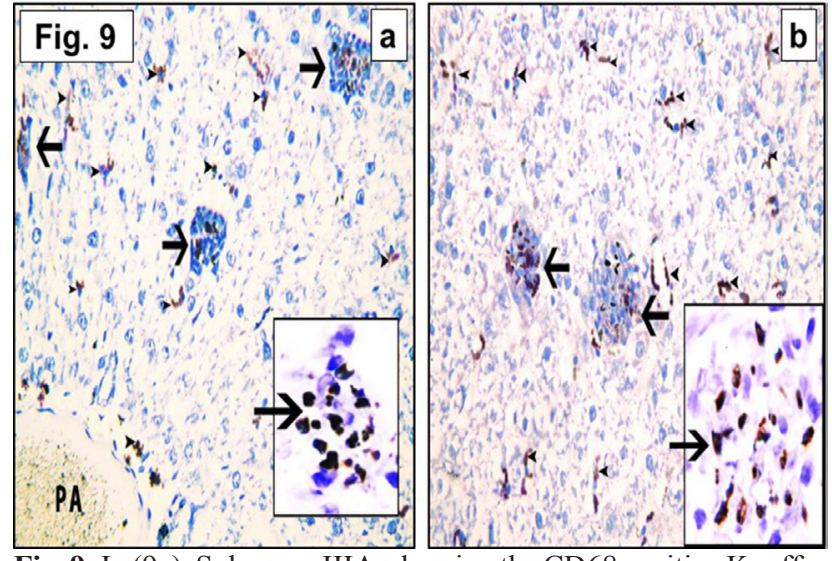

Fig. 9: In (9a): Subgroup IIIA, showing the CD68 positive Kupffer cells ( $\boldsymbol{\Delta})$ lining the blood sinusoids. Positive immunoreaction to CD68markercanbealsonoticedinmacrophages of themononuclear cellular aggregations ( $\uparrow)$. (9b): Subgroup IIIB, showing CD68 positive Kupffer cells in sinusoidal lining $(\boldsymbol{\Delta})$ and CD68 positive macrophages in the mononuclear cellular aggregations ( $\uparrow$ ).

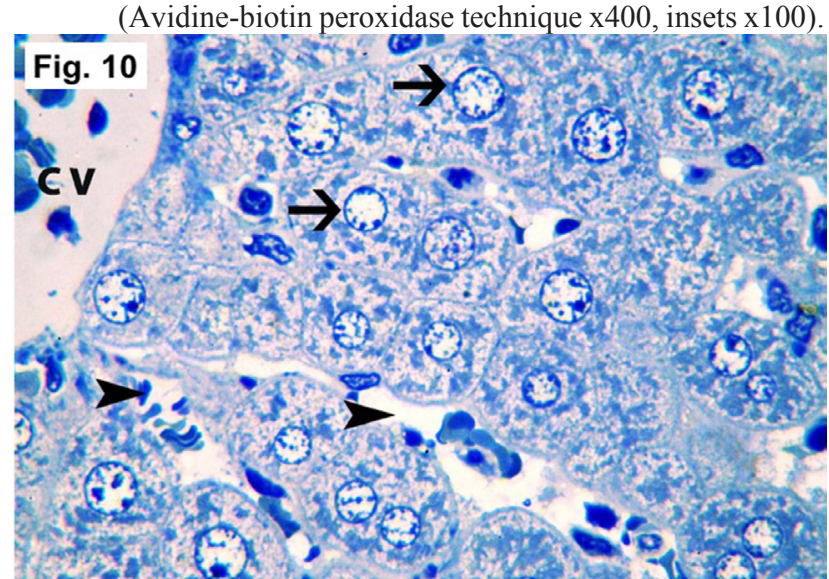

Fig. 10: A semithin section of the control group showing a part of a central vein $(\mathrm{CV})$ with radiating branching and anastomosing cords of hepatocytes. Hepatocytes appear polygonal with vesicular rounded nuclei $(\uparrow)$. Blood sinusoids lined with endothelial cells containing blood cells are seen between the cords of hepatocytes $(\mathbf{\Delta})$. (Toluidine Blue x1000).
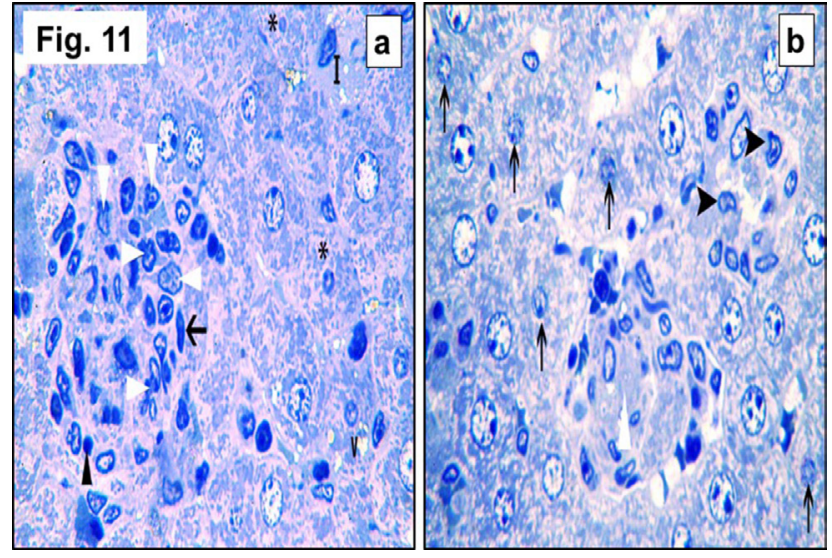

Fig. 11: Semithin sections (11a): Subgroup IIA, showing cytoplasmic vacuolization (V) in some hepatocytes and small deeply stained nuclei $(*)$ in others. Aggregation of mononuclear cells containing macrophages (white $\Delta$ ), fibroblast-like cells $(\uparrow)$ and lymphocytes $(\boldsymbol{\Delta})$. Notice Ito cells containing many fat droplets (I). (11b): Subgroup IIB, showing hepatocytes with apparently small nuclei $(\uparrow)$. Mononuclear cellular aggregations can be seen containing few cells mostly macrophages $(\boldsymbol{\Lambda})$. Notice the structureless material in the center of the aggregate (white $\Delta$ ).

(Toluidine Blue x1000).

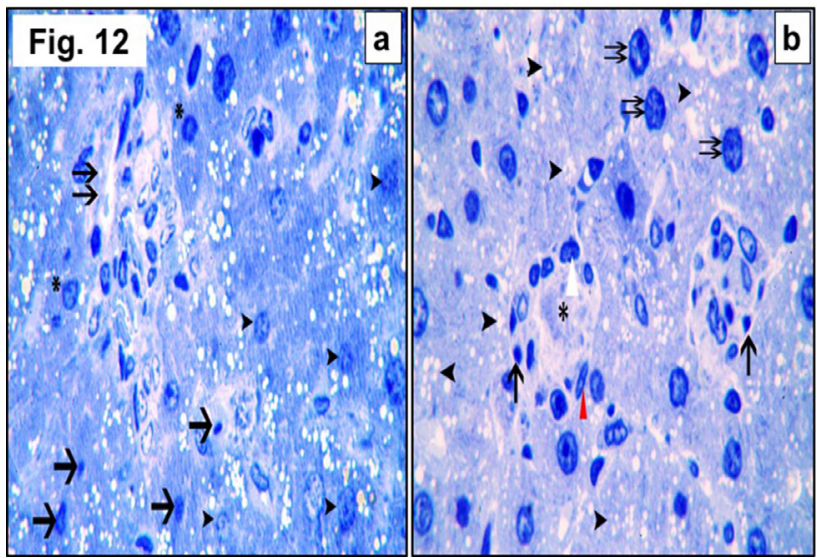

Fig. 12: Semithin sections (12a): Subgroup IIIA, showing hepatocytes studded with many fat droplets $(*)$. Notice faintlystained $(\mathbf{\Delta})$ or pyknotic nuclei $(\uparrow)$. A mononuclear cellular aggregation $(\uparrow \uparrow)$ can be seen. (12b): Subgroup IIIB, showing hepatocytes with many cytoplasmic fat droplets (black $\mathbf{\Delta}$ ). Notice hepatocytes with irregularly-outlined nuclei $(\uparrow \uparrow)$. Mononuclear cellular aggregations are noticed with relatively pale center $(*)$. macrophages $(\Delta)$, lymphocytes $(\uparrow)$ and fibroblast-like cells (red $\mathbf{\Delta}$ )

(Toluidine Blue x1000).

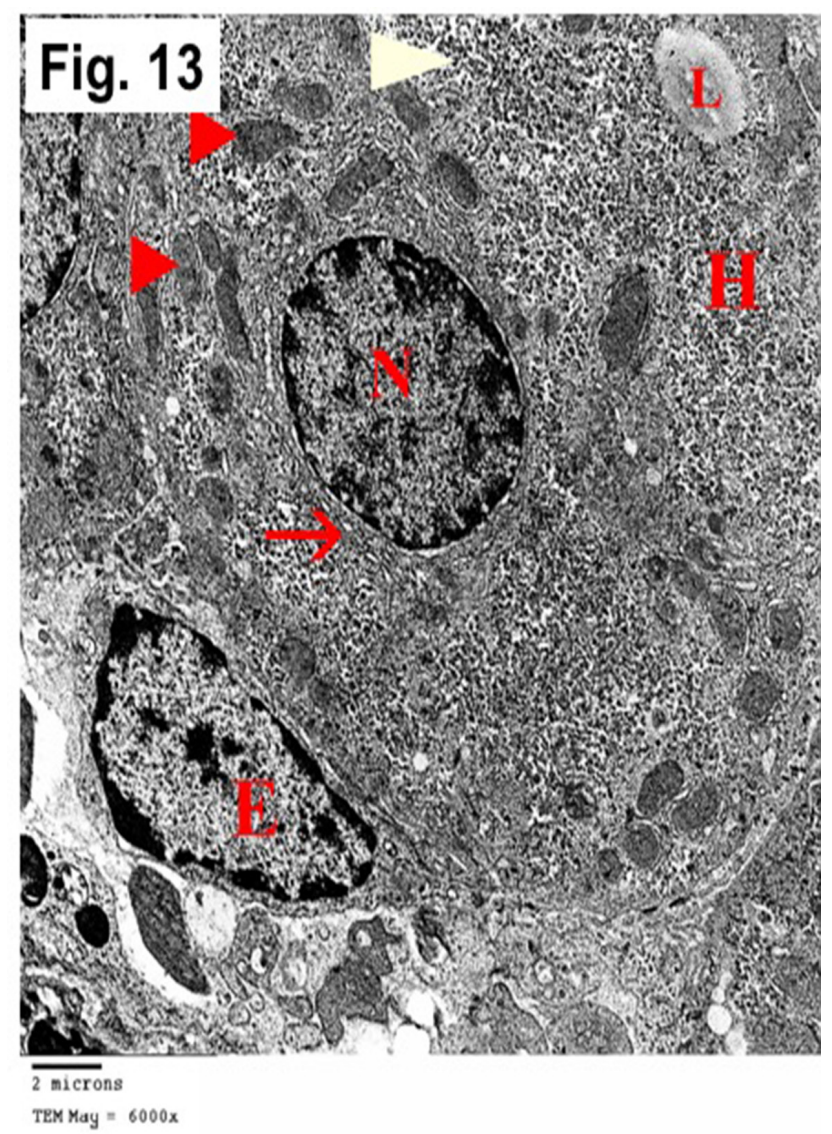

Fig. 13: Control group showing a hepatocyte $(\mathrm{H})$ having a single electron lucent nucleus $(\mathrm{N})$. Notice the rER surrounding the nucleus $(\uparrow$ ), scattered mitochondria (red $\boldsymbol{\Lambda}$ ), glycogen rosettes (white $\Delta$ ) and a lipid globule (L). An endothelial cell having an euchromatic nucleus (E) is seen lining a blood sinusoid.

(TEM x8000). 


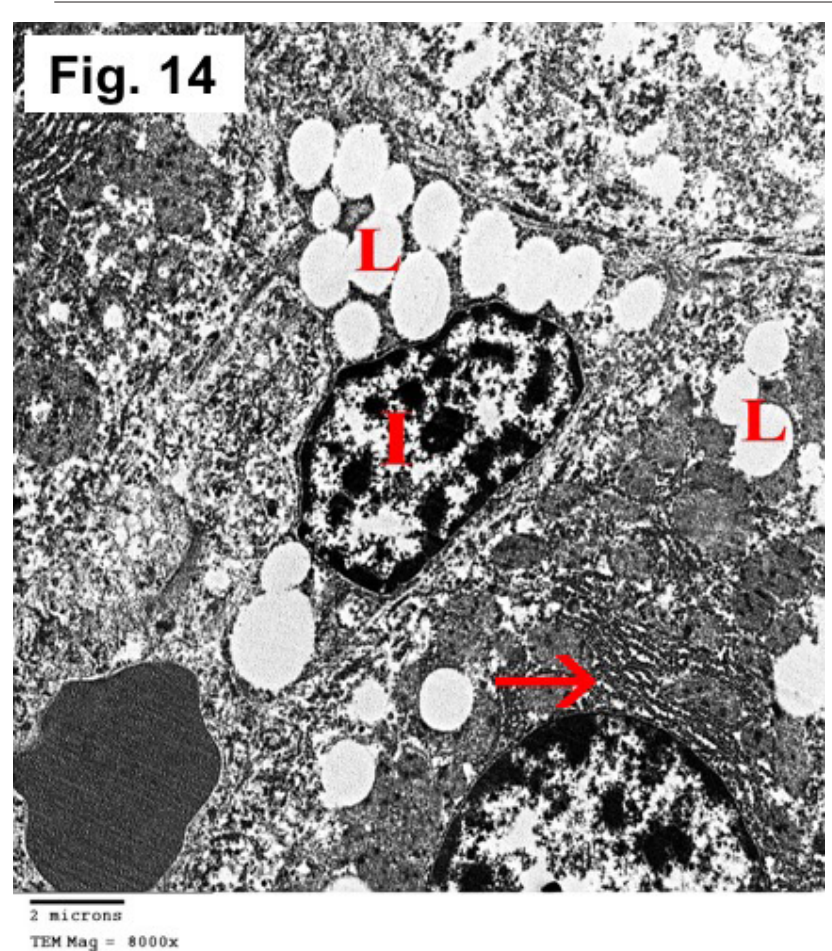

Fig. 14: Control group showing space of Disse containing Ito cell (I) closely related to hepatocytes $(\mathrm{H})$. Notice many electron lucent lipid droplets (L) in cytoplasm of hepatocytes and Ito cells. Regular perinuclear rER can be seen in the hepatocyte ( $\uparrow)$.

(TEM x 8000).

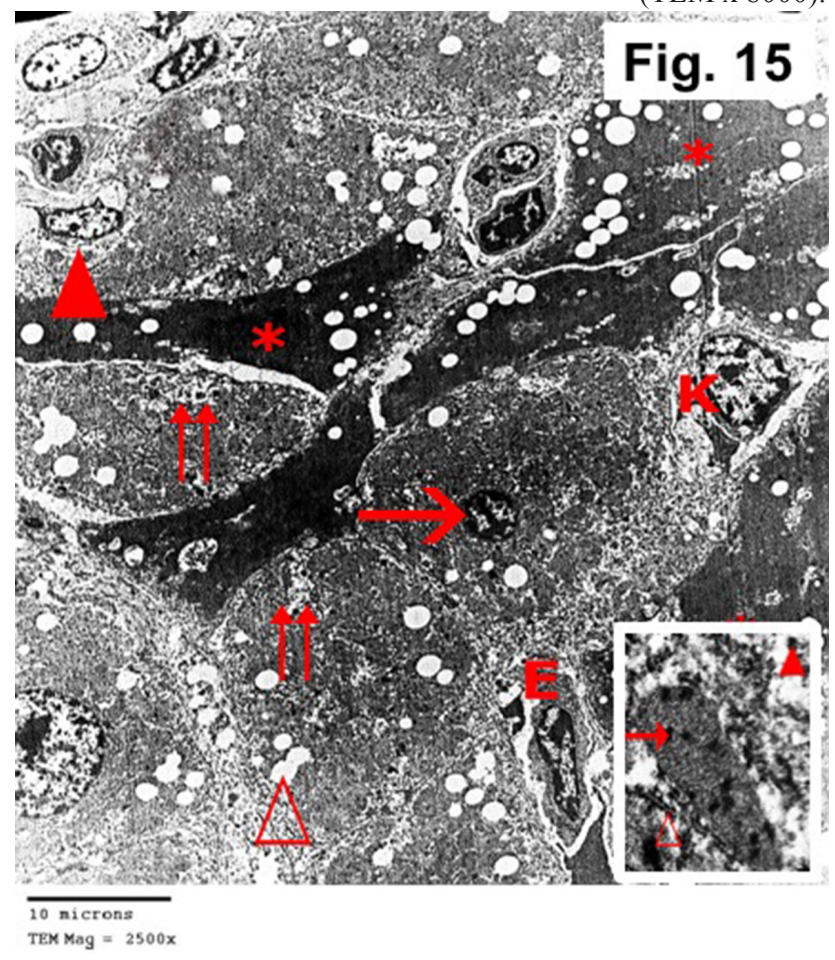

Fig. 15: Subgroup IIA showing cells having electron dense cytoplasm, multiple processes and lipid droplets $(*)$. Hepatocytes with small electron dense nuclei are seen $(\uparrow)$. Multiple electron lucent lipid droplets can be noticed in all hepatocytes $(\Delta)$. Electron lucent areas filled with granular material can be noticed inside hepatocytes $(\uparrow \uparrow)$. Endothelial cell (E) and Kupffer cells $(\mathrm{K})$ can be seen. Notice many inflammatory cells among hepatocytes (red $\boldsymbol{\Delta}$ ). Inset shows electron dense particles in mitochondrial matrix $(\uparrow)$ and in the hepatocytes cytoplasm $(\boldsymbol{\Delta})$.

(TEM x2500, inset x 30000).

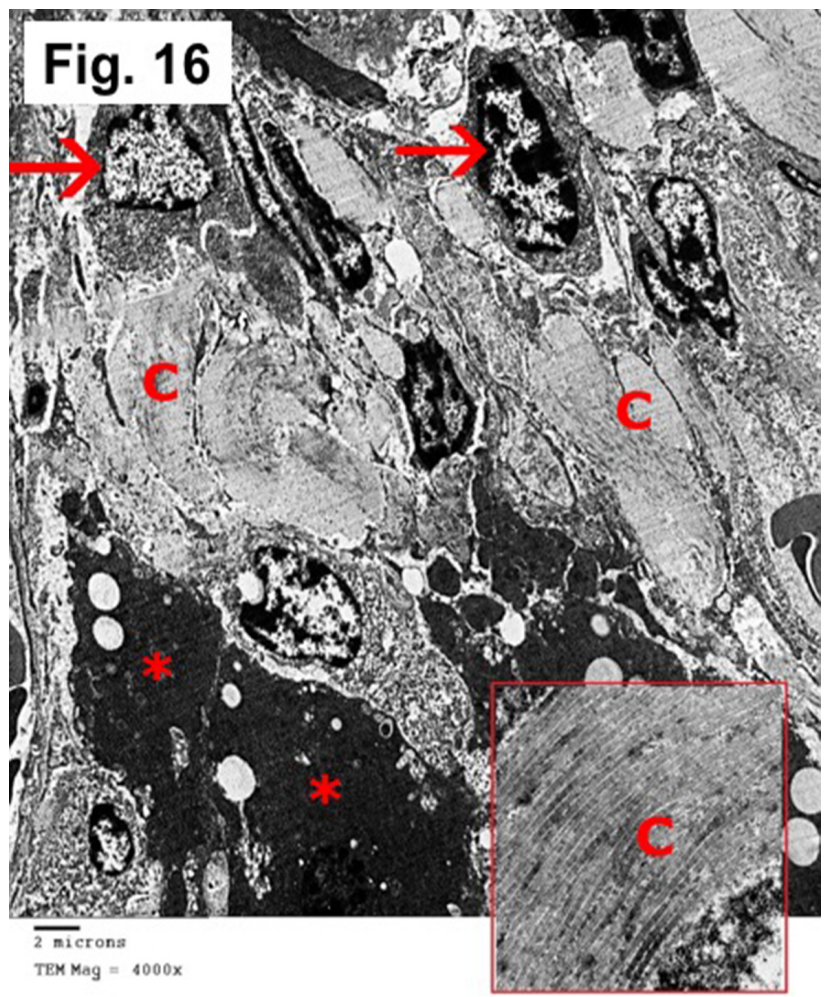

Fig. 16: Subgroup IIA, showing aggregation of mononuclear cells $(\uparrow)$ with collagen fibrils in-between (C). Notice the branched electron dense cells containing lipid droplets at the periphery of the aggregate $(*)$.

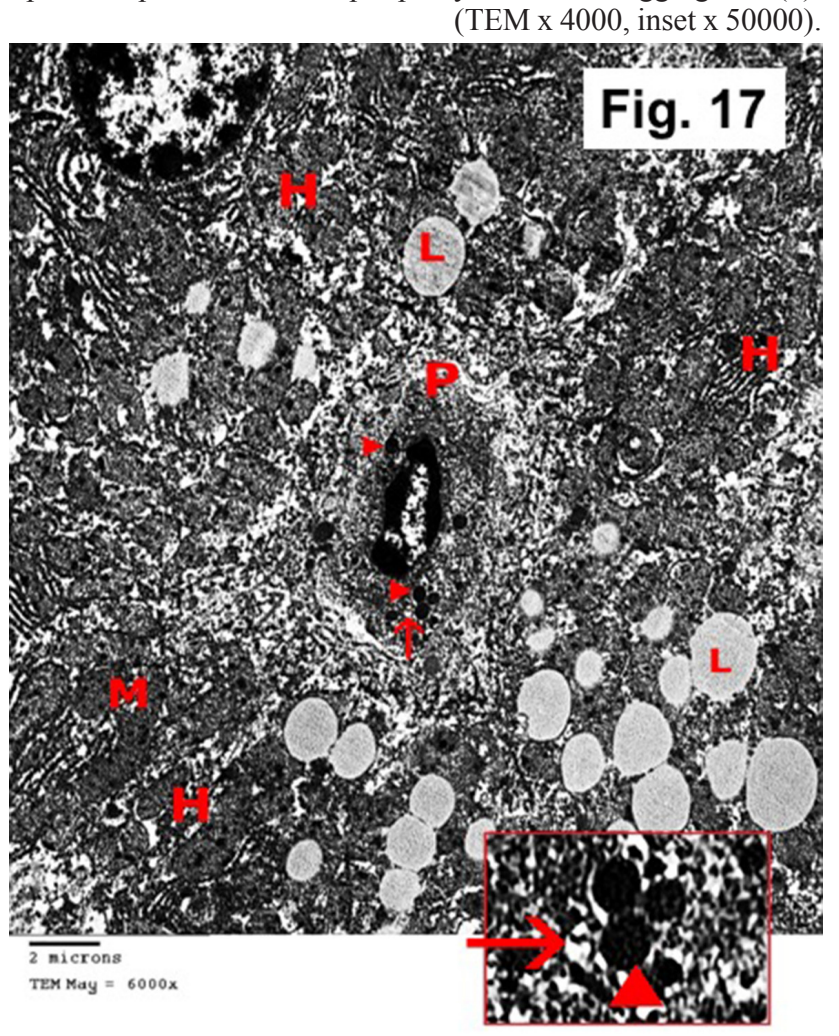

Fig. 17: Subgroup IIA showing a pit cell (P) in sinusoidal lumen extending their short cytoplasmic processes. Dense granules ( $\boldsymbol{\Delta})$ and rod-cored vesicles $(\uparrow)$ are seen in the pit cell cytoplasm. Notice numerous mitochondria (M) and multiple lipid droplets (L) inside cytoplasm of nearby hepatocytes $(\mathrm{H})$. Inset shows a higher magnification of dense granules $(\mathbf{\Lambda})$ and rod-cored vesicles $(\uparrow)$ of the pit cell. (TEM x6000, inset x20000). 


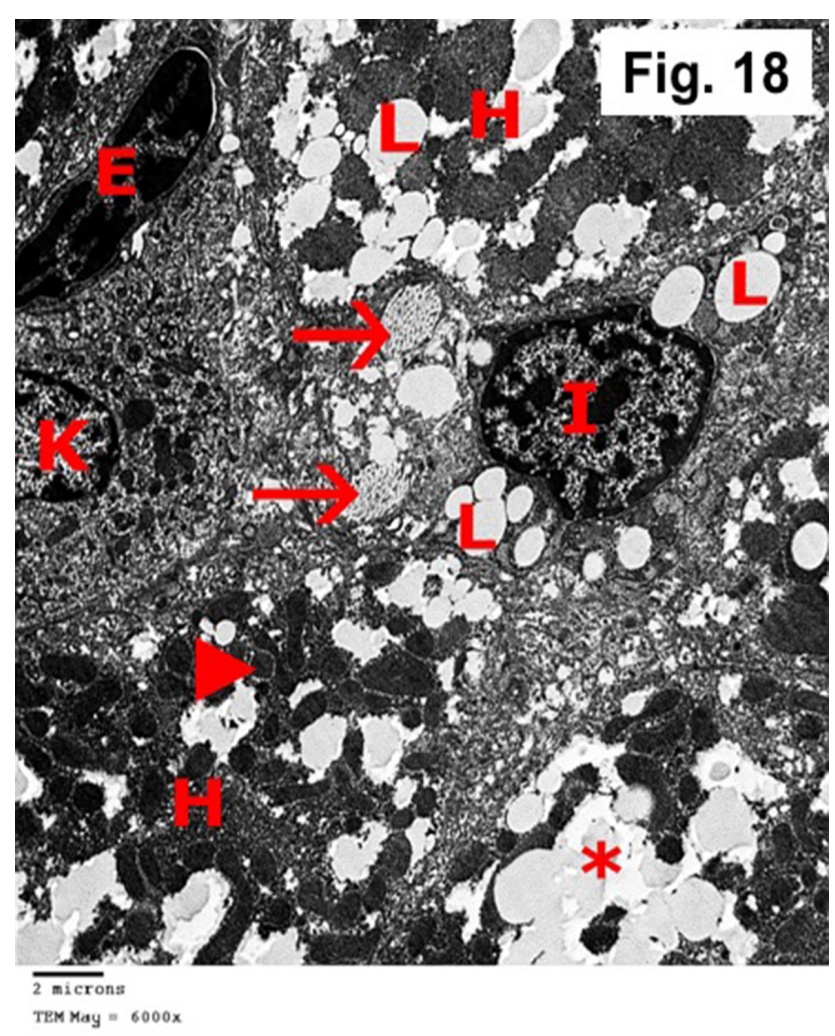

Fig. 18: Subgroup IIB showing hepatocytes with electron dense mitochondria having unapparent cristae $(\boldsymbol{\Delta})$. Confluent electron lucent areas containing homogenous material $(*)$ can be seen inside hepatocytes cytoplasm $(\mathrm{H})$ as well as lipid droplets (L). Notice collagen fibrils deposition ( $\uparrow$ ) besides Ito cell (I). Part of a kupffer cell (K) can be observed adjacent to an endothelial cell (E).

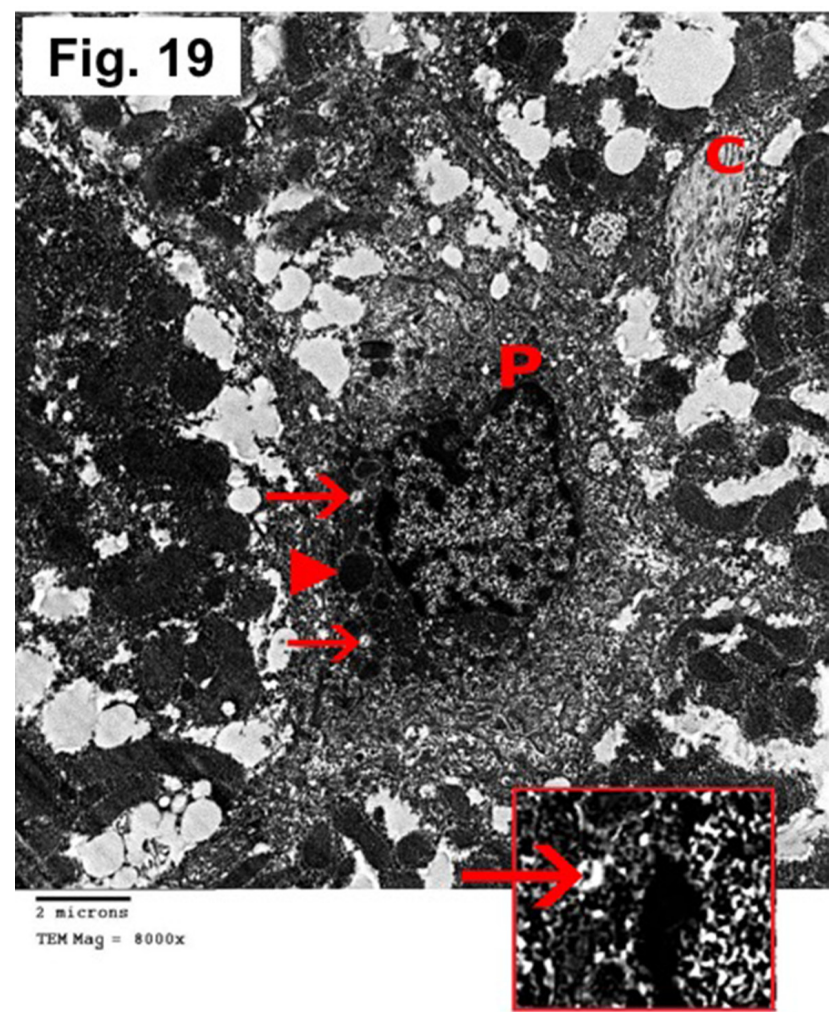

Fig. 19: Subgroup IIB showing pit cell (P) in sinusoidal lumen having cytoplasmic processes. Dense granules (red $\boldsymbol{\Delta}$ ) are seen in the pit cell cytoplasm at one side of the nucleus as well as few rod cored vesicles $(\uparrow)$. Collagen is seen deposited in between hepatocytes $(\mathrm{C})$.

(TEM x 8000, inset x 20000).

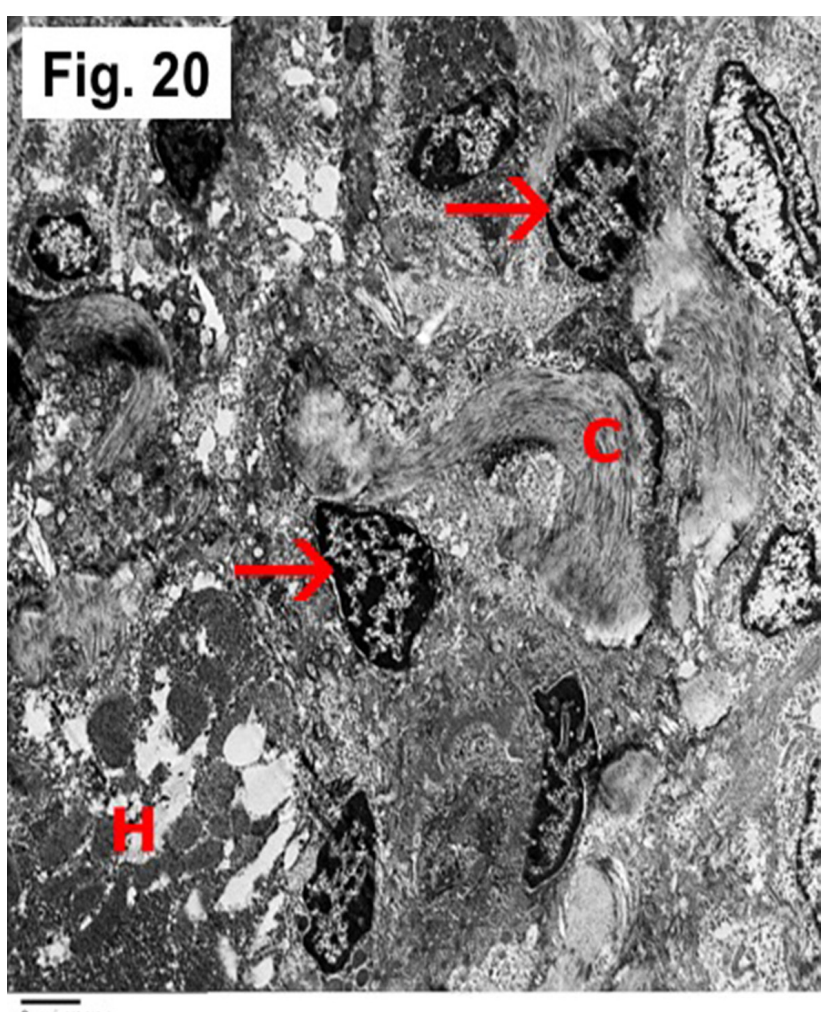

$\overline{2 \text { mierons }}$

TEM Mag $=5000 x$

Fig. 20: Subgroup IIB showing collagen fibrils (C) in-between the aggregation of mononuclear cells.

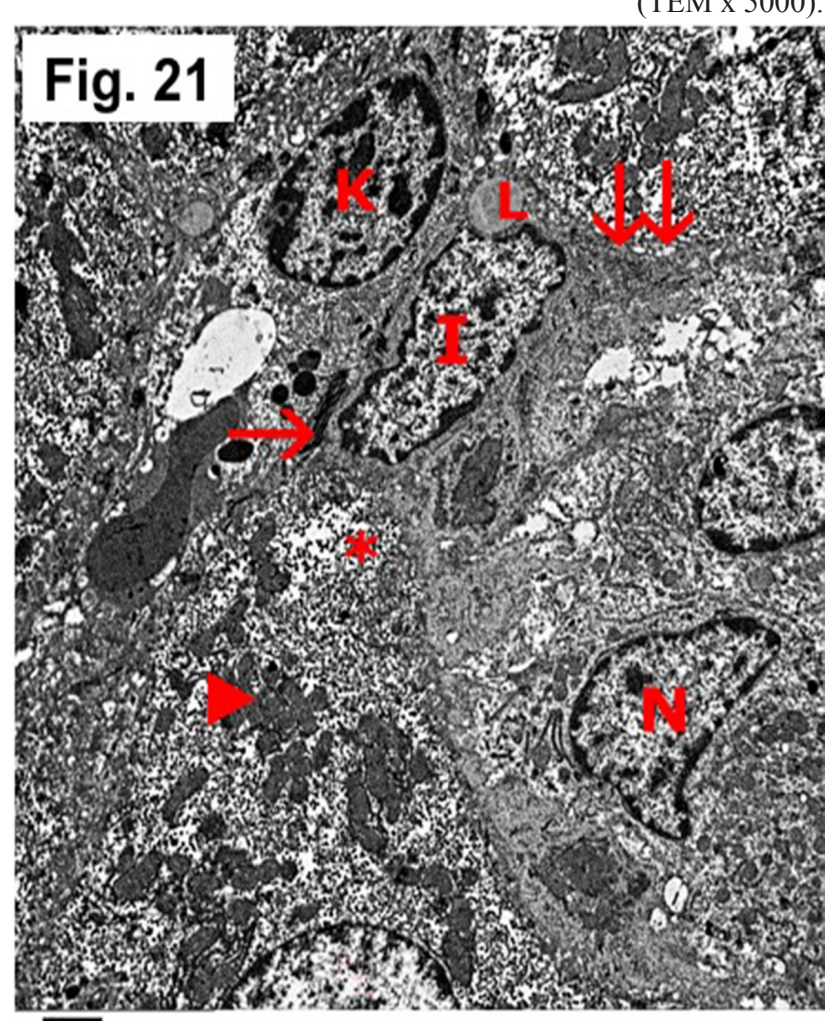

2nicrons
TEM Mag = $5000 \mathrm{x}$

Fig. 21: Subgroup IIIA showing hepatocytes with irregular euchromatic nuclei $(\mathrm{N})$. Numerous mitochondria with apparent cristae are seen grouped in the cytoplasm of hepatocytes $(\boldsymbol{A})$. Ito cell (I) can be observed having cytoplasmic processes ( $\uparrow$ ), euchromatic nucleus and a lipid droplet (L). Notice little collagen fibrils deposited adjacent to Ito cell ( $\uparrow$ ). A Kupffer cell (K) can be seen.

(TEM x 5000) 


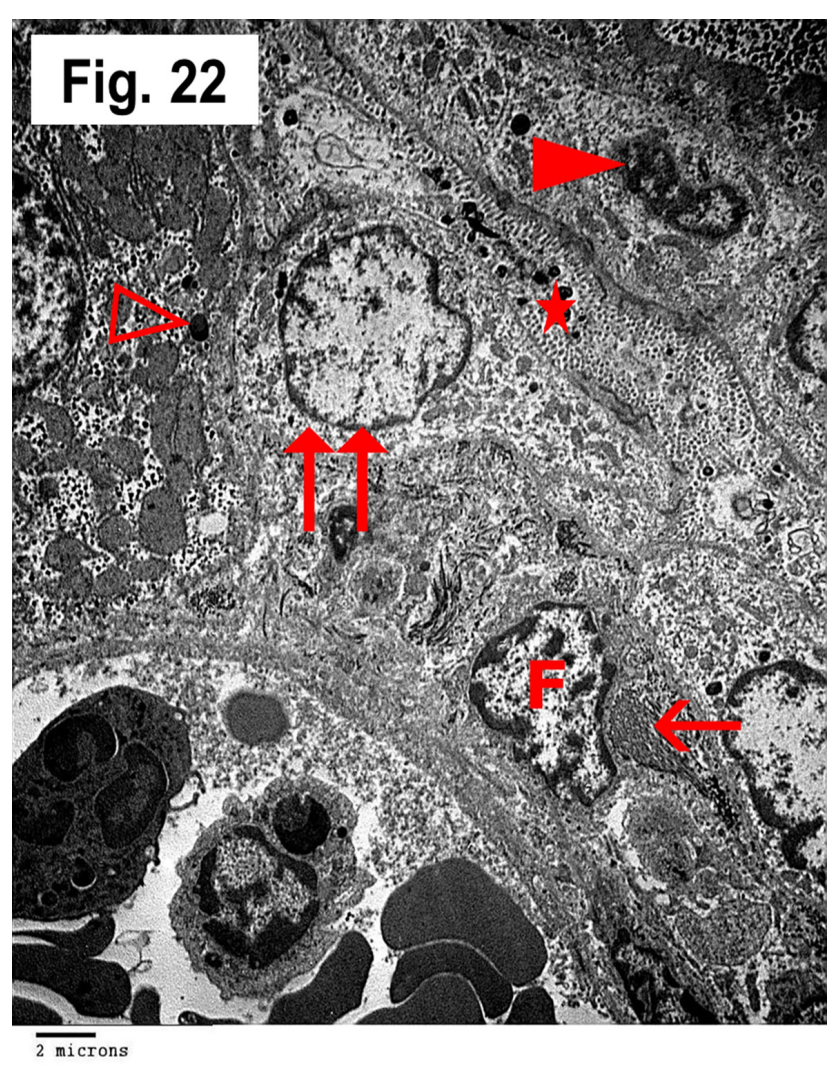

TEM Mag $=5000 \mathrm{x}$

Fig. 22: Subgroup IIIA showing an oval cell in the periportal area $(\uparrow \uparrow)$. Notice hepatocyte with small irregular nucleus $(\boldsymbol{\Delta})$.

Some electron dense granules can be seen in the space of Disse $(*)$ and in the cytoplasm of hepatocytes $(\Delta)$. A myofibroblast can be observed $(F)$ with adjacent collagen fibrils $\quad$ (TEM x 5000).

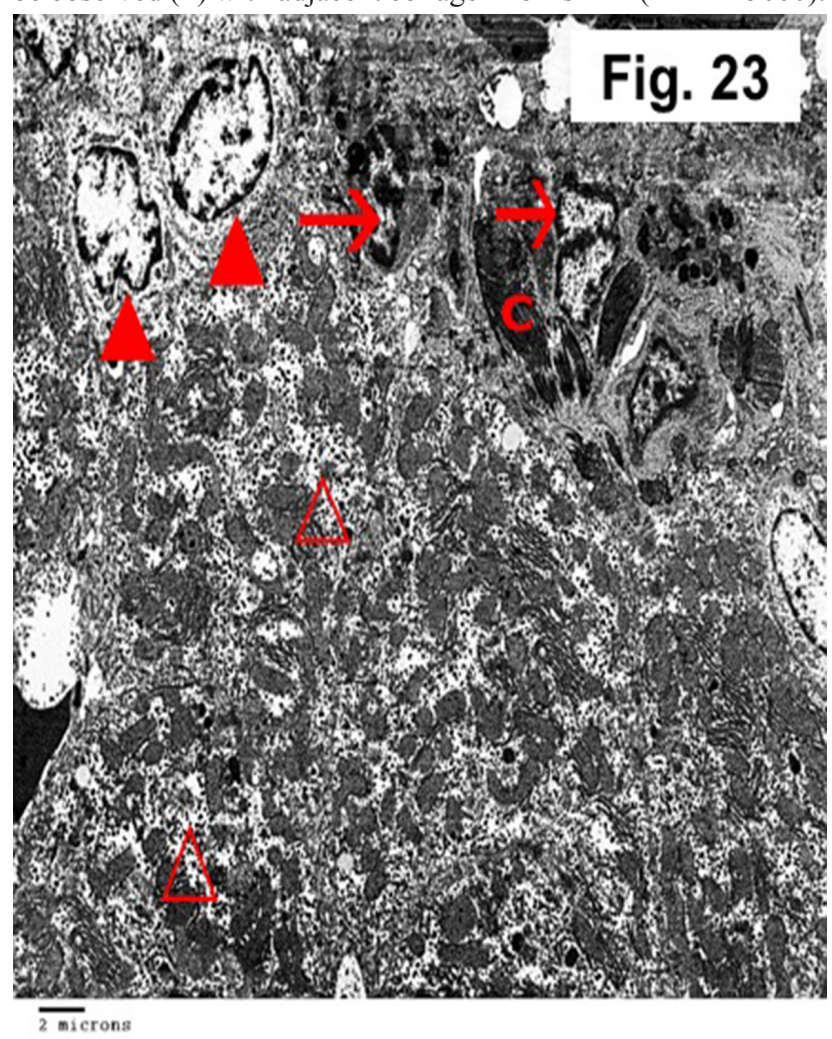

TEM Mag $=4000 x$

Fig. 23: Subgroup IIIA showing collagen fibrils (C) in-between aggregation of mononuclear cells $(\uparrow)$. Oval cells can be seen $(\boldsymbol{\Delta})$. Electron dense granular material can be observed inside the cytoplasm of hepatocytes $(\Delta)$.

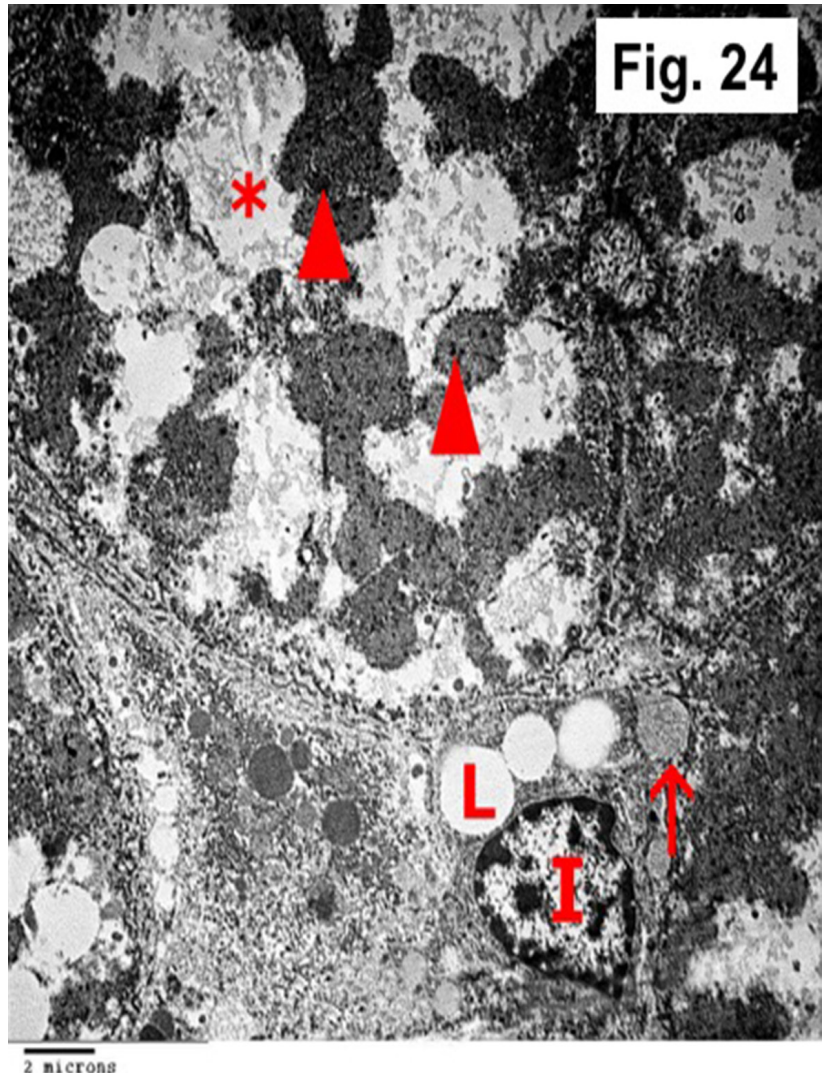

TeM May $=6000 x$

Fig. 24: Subgroup IIIB showing hepatocytes with many wide electron lucent areas containing electron lucent granular materia $\left.{ }^{*}\right)$. Groups of fused mitochondria can be seen within electron dense matrix deposits ( $\boldsymbol{\Delta})$. An Ito cell (I) is seen containing multiple lipid droplets (L) with nearby collagen deposition ( $\uparrow$ ).

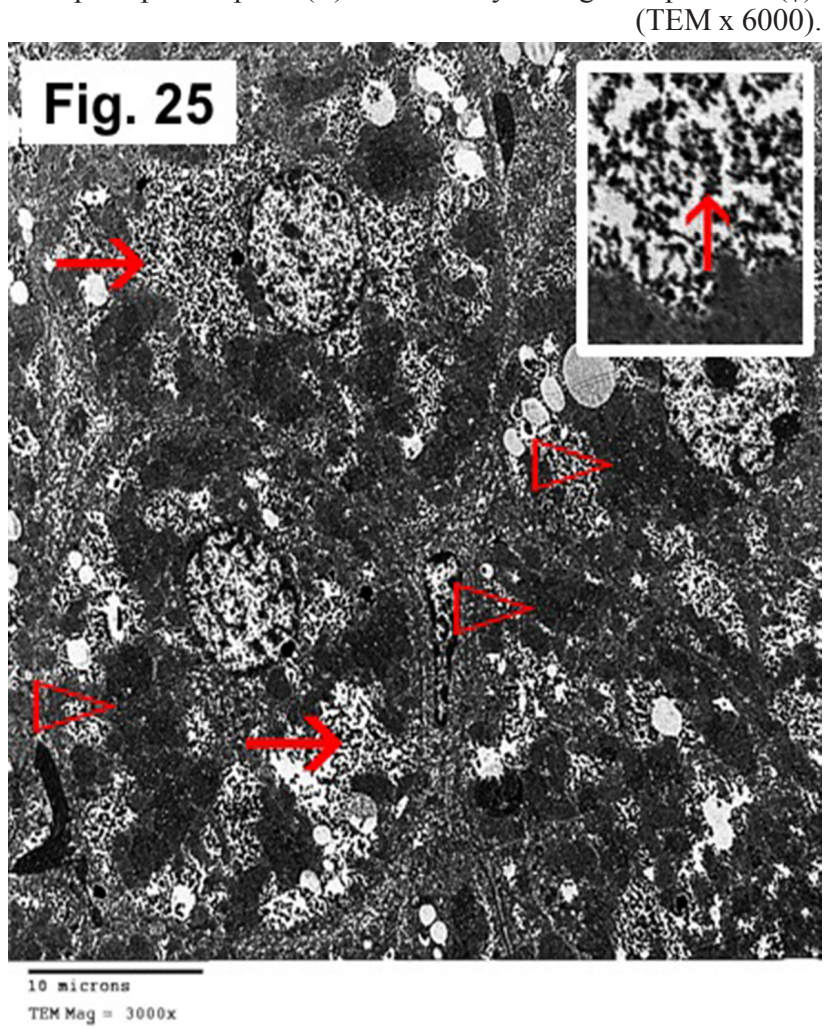

Fig. 25: Subgroup IIIB showing the cytoplasm of hepatocytes filled with electron dense granules $(\uparrow)$ in-between electron dense mitochondria $(\Delta)$. The inset shows higher magnification of the electron dense granules $(\uparrow)$. 


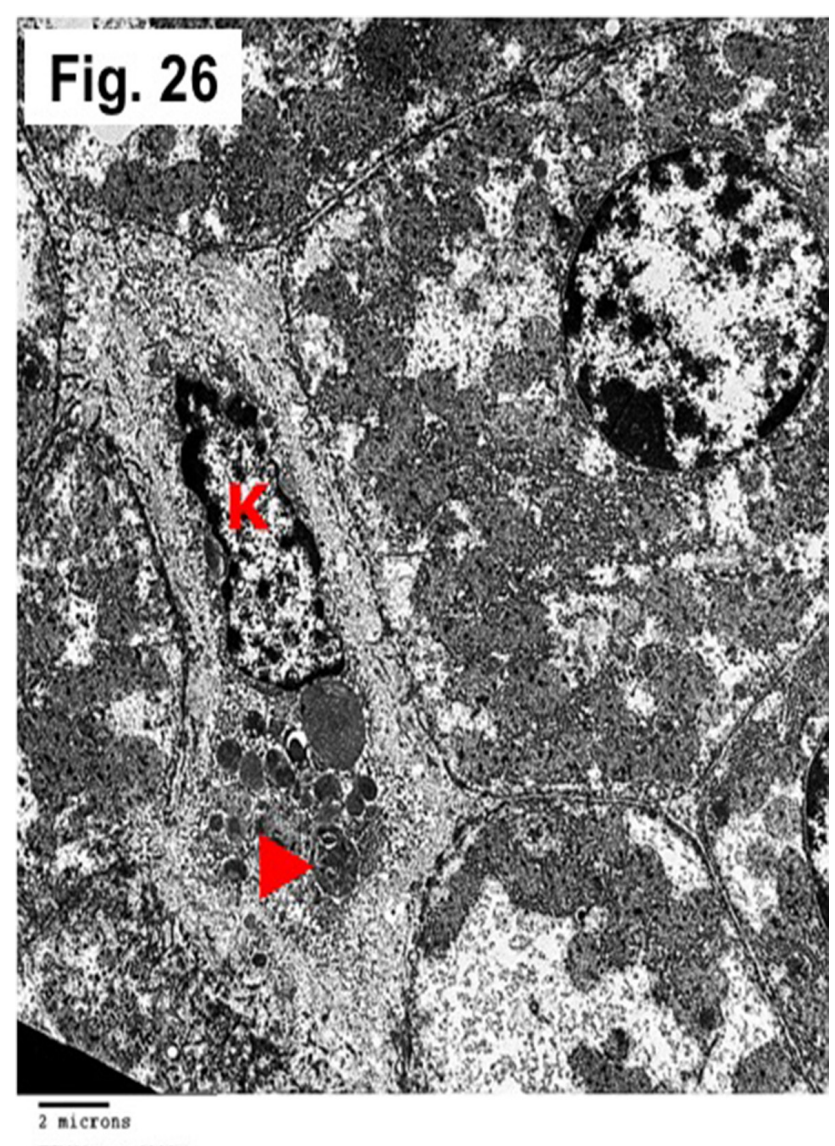

TEK May $=6000 x$

Fig. 26: Subgroup IIIB showing a large Kupffer cell (K) inbetween the hepatocytes with multiple heterolysosomes $(\mathbf{A})$. (TEM x 6000)

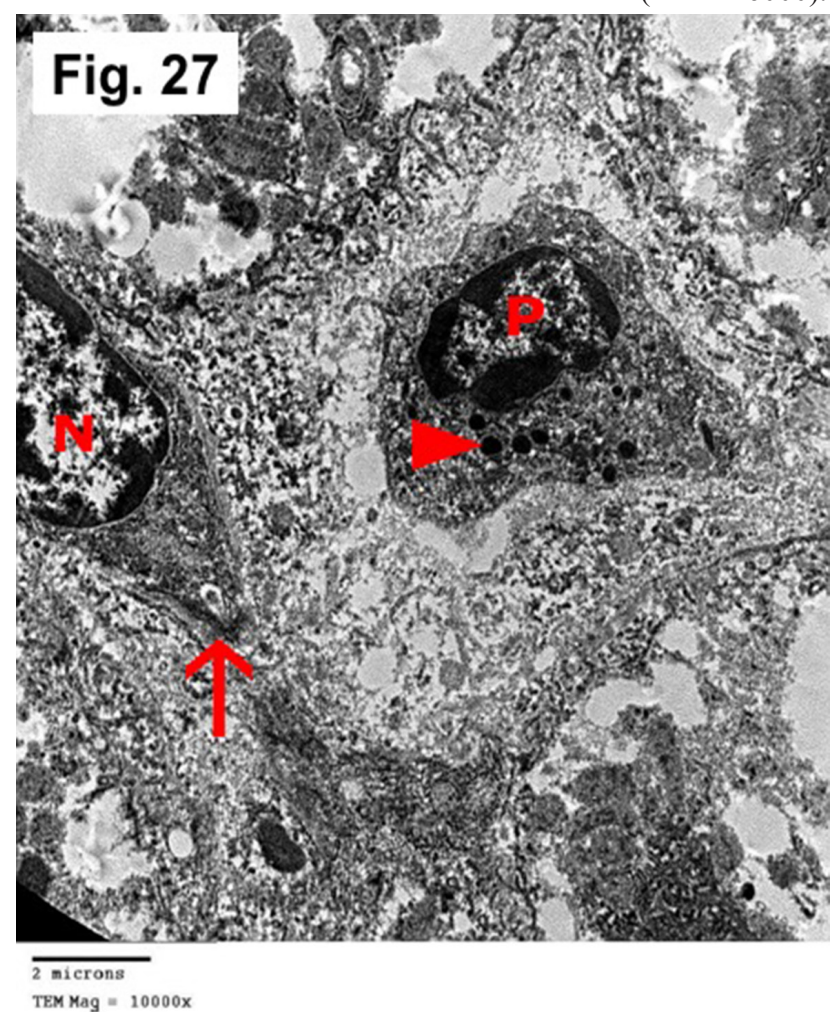

Fig. 27: Subgroup IIIB showing pit cell (P) in sinusoidal lumen with cytoplasmic processes and cytoplasmic dense granules $(\boldsymbol{\Delta})$. Notice a part of a myofibroblast showing oval electron lucent nucleus $(\mathrm{N})$ and spindle shaped cytoplasmic processes $(\uparrow)$. (TEM x10000).

\section{DISCUSSION}

The size of $\mathrm{SiO}_{2}$ NPs used in this study ranged between $40 \mathrm{~nm}$ and $60 \mathrm{~nm}$. The small size of NPs was reported to attribute to their high surface area. This increase their binding to serum proteins, and promote their surface receptor recognition, leading to more tissue harm than larger sized $\mathrm{NPS}^{[22]}$.

Hepatocytes' cytoplasmic granules were detected in subgroup IIIB by H\&E stain, and in all subgroups by TEM. The granules were also seen in the mitochondrial matrix in all subgroups. These granules were most probably the $\mathrm{SiO}_{2} \mathrm{NPs}$. They were more obviously seen with increasing the time and duration of NPs administration. These results were in accordance with a previous research which suggested that NPs with sizes less than $100 \mathrm{~nm}$ could pass freely through the fenestrae of endothelial cells lining the hepatic sinusoids to the space of Disse. Larger sized NPs would not pass as the fenestrae are approximately $100 \mathrm{~nm}$ in diameter ${ }^{[19]}$. It was also reported that $\mathrm{SiO}_{2} \mathrm{NPs}$ adhered in vitro to cell surface in clusters or in individual form and dispersed in the cytoplasm, mitochondria and lysosomes. The NPs were proved to enter the cytoplasm by diffusion through membrane or by an adhesive interaction in an endocytosis-independent pathway. It was therefore suggested that NPs could penetrate any other organelle in the cytoplasm as mitochondria by the same way ${ }^{[23]}$.

In the current study, cytoplasmic vacuolizations were seen by H\&E stain in the hepatocytes of Zone (I) near portal areas. These vacuolizations were seen by TEM either as multiple fat droplets or as electron lucent areas that could be due to cellular injury. Moreover, karyolytic and pyknotic nuclei of some hepatocytes also appeared in many sections. In this context, it was stated that fatty change is a form of reversible cellular injury occurring due to toxic, metabolic or hypoxic insult, in contrast, the nuclear changes were irreversible which denoted variable degrees of necrotic cellular injury ${ }^{[24]}$.

The mitochondria in the present study were numerous and apparently increased in size in all experimental subgroups and contained electron dense granules, mostly $\mathrm{SiO}_{2}$ electron dense NPs. This could be explained on basis that mitochondria adapted stress by means of mitochondrial biogenesis in order to increase the number and activity of their critical enzymes to endure the growing stress ${ }^{[25]}$. Moreover, functionally impaired mitochondria through membrane permeabilization, inhibition of fatty acid oxidation or mitochondrial DNA depletion appeared morphologically swollen, with electron dense inclusions in their matrix. This was reported to cause overproduction of reactive oxygen species (ROS) ${ }^{[26]}$. In addition, NPs internalization into mitochondria 
might cause direct injury which eventually lead to total cell injury and initiation of apoptotic pathways ${ }^{[23]}$.

The mitochondrial damage might be linked to fatty change seen in the hepatocytes of the present study. Mitochondrial dysfunction was claimed to cause lipid accumulation in the cells, apoptosis or necrosis leading to hepatic cytolysis and inflammation ${ }^{[27]}$. Moreover, toxin-induced injury is usually associated with steatosis in the liver in which the mitochondria show pleomorphic enlargement, and disruption or complete loss of cristae ${ }^{[24]}$. This was also in accordance with a previous study which attributed the mitochondrial damage to occurrence of lipid peroxidation ${ }^{[28]}$.

All experimental subgroups in the current work revealed the presence of multiple scattered well defined aggregations of mononuclear inflammatory cells in the hepatic parenchyma composed mainly of macrophages as detected by CD68 immunostaining, toluidine blue staining and by TEM examination. These aggregations, were suggested as a type of delayed type IV hypersensitivity granulomatous reaction in which, T-helper (Th) lymphocytes accompanied by macrophages accumulate in the perivascular areas. With prolonged time, macrophages replace the Th lymphocytes, become larger, flat and eosinophilic forming epithelioid cells. Eventually, fibroblast-like cells and connective tissue enclose the granulomas giving its characteristic rounded shape ${ }^{[24]}$.

The presence of obvious increased collagen upon $\mathrm{SiO}_{2} \mathrm{NPs}$ administration in the present study, illustrated by TEM examination, could be highly correlated with the presence of Ito cells and fibroblastlike cells. The Ito cells were few and containing multiple lipid droplets in the control group. However, in the experimental subgroups, some of these cells contained few fat droplets and were seen nearby collagen fibrils deposition, denoting their attribution in secreting these collagen fibrils. In injured liver, Ito cells (hepatic stellate cells) were reported to transform into an activated phenotype, in which they lose lipid droplets, and transform into myofibroblast with high proliferative capacity. They developed rER, extensive mitochondria and bundles of actin filaments that made them positive for $\alpha$ smooth muscle actin antibody ${ }^{[29]}$. This activation to collagen producing myofibroblast was considered a pivotal point for the development of liver fibrosis ${ }^{[30]}$.

Several mechanisms were suggested for Ito cell transformation; namely interaction with each other via autocrine and paracrine loops causing self-preservation and fibrogenesis, activation by transforming growth factor beta (TGF- $\beta$ ) secreted by activated Kupffer cells and damaged hepatocytes. Additionally, they could be activated by cytokine secretions and ROS mediators released from inflammatory cells, platelets and endothelial cells ${ }^{[31]}$.

Although Ito cells were found to give rise to 82$96 \%$ of myofibroblasts in the liver ${ }^{[32]}$, other potential sources were assumed as bone marrow derived circulating fibrocytes ${ }^{[33]}$, and portal fibroblasts ${ }^{[34]}$. However, the extent of their role remains negligible and controversial ${ }^{[30]}$. Most recently, the epithelialmesenchymal transition (EMT) was proposed as one of the highly potential sources of hepatic myofibroblasts, and was reported to have a cardinal role in fibrosis as well as cancer formation and ability of malignant cells to metastasis ${ }^{[35]}$. Namely, the hepatocytes and cholangiocytes were potentially implicated in this process. They were shown to lose their epithelial characteristics and acquire mesenchymal phenotypes such as motility, migratory ability and invasiveness ${ }^{[30]}$.

In this view, the hepatocytes detected in the current study with branched dark eosinophilic cytoplasm at the periphery of some granulomas by H\&E stain in subgroup IIB, or seen by TEM as branched electron dense cells with lipid droplets in subgroup IIA, were suggested to be hepatocytes in a transformation process into myofibroblast.

Pit cells were identified in all subgroups of the present study by TEM examination. The cells possessed electron dense granules, mostly on one side of the nucleus, together with their characteristic rodcored vesicles and few organelles. Pit cells are now known to be the hepatic natural killer (NK) cells, they were considered as intra hepatic lymphocytes present in the sinusoidal lumen that differ from the visiting blood cells typically present in hepatic sinusoids. They mediate their killing cytotoxicity through their electron dense granules which were formed in their Golgi apparatus. They were reported to contain perforin, granzymes as well as acid phosphatase enzyme. Pit cells were also characterized by rod cored vesicles exhibiting an electron dense rod completely bridging their entire diameter ${ }^{[36]}$. Pit cells were reported to migrate along the sinusoid by pseudopodia. These cells retain similarities to peripheral blood NK cells; however, they were seen larger in size with more numerous electron dense granules. Functionally, pit cells were more cytotoxic to transformed cells ${ }^{[37]}$.

Accumulating evidence showed that NK cells and Kupffer cells were functionally related as their number and activity rise or fall together indicating an existing synergism between both cell types. Moreover, they were often seen as neighbors, contacting each other ${ }^{[38]}$. Additionally, Pit cells (hepatic NK cells) were also functionally correlated with Ito cells (hepatic stellate cells). Hepatic NK cells inhibited liver fibrosis by producing interferon-gamma (IFN- $\gamma$ ) which kill early 
activated hepatic stellate cells ${ }^{[39]}$, or via induction of hepatic stellate cell apoptosis ${ }^{[40]}$. In contrast, it was stated that TGF- $\beta$ produced from Ito cells of cirrhosed livers suppressed NK cells' killing capacity and IFN- $\gamma$ production, and induced NK apoptosis through cell emperipolesis (i.e. a cell-in-cell structure), in which hepatic stellate cells internalize the functionally impaired NK cells, thus promoting the progression of liver fibrosis ${ }^{[41]}$.

Oval cells were detected by TEM examination in the present study, in subgroup IIIA. They were seen as if they were wondering in the periportal area by their pseudopodia. They had their characteristic large nuclear: cytoplasmic ratio, nucleus with sparse euchromatin and few cytoplasmic organelles. It has been reported that these oval cells are the hepatic stem cells residing in the canal of Herring. These hepatic stem cells were found in the portal and peripheral areas in experimental animals where they differentiate into bile ductular cells or hepatocytes allowing repopulation of the injured liver ${ }^{[42]}$. Moreover, oval cells might differentiate to hepatic stellate cells with myofibroblast morphological features ${ }^{[43]}$. Recently, proliferation and differentiation of oval cells was attributed to activation of certain genes and specific growth factors as tumour necrosis factor (TNF) superfamily, hepatocyte growth factor, epidermal growth faction, TGF- $\beta$ and fibroblast growth factors ${ }^{[44]}$.

In conclusion, $\mathrm{SiO}_{2} \mathrm{NPs}$ induced focal structural changes in hepatocytes, focal inflammatory response in the liver and focal fibrosis in periportal area and around the granulomas, even at the low dose of $10 \mathrm{mg} / \mathrm{kg} /$ day. This response was augmented with increasing dose and duration of administration. Thorough investigations are needed to further elucidate the interplay between hepatocytes and other non-parenchymal hepatic cells. Further in-depth studies are needed to explore the effect of $\mathrm{SiO}_{2} \mathrm{NPs}$ administration on different body organs, using different doses and durations, before $\mathrm{SiO}_{2}$ NPs can be safely used.

\section{CONFLICT OF INTEREST}

There are no conflicts of interest.

\section{REFERENCES}

1. Kim Y R, Park S H, Lee J K, Jeong J, Kim J H, Meang $\mathrm{H}$ and Yoon TH. Organization of research team for nano-associated safety assessment in effort to study nanotoxicology of zinc oxide and silica nanoparticles. Int J Nanomed 2014; 9:3-10

2. Walter P, Welcomme E, Hallégot P, Zaluzec NJ, Deeb C, Castaing J, Veyssière P, Bréniaux R, Lévêque JL, Tsoucaris G. Early use of $\mathrm{PbS}$ nanotechnology for an ancient hair dyeing formula. Nano Lett 2006; $10: 2215-2219$

3. Nel A, Xia T, Madler L and Li N.Toxic potential of materials at the nanolevel. Science 2006; 311:622627.

4. Yildirimer L, Thanh NTK, Loizidou $M$ and Seifalian AM. Yoxicological considerations of clinically applicable nanoparticles. Nano Today 2011; 6: 585-607.

5. Lara $\mathrm{Y}$, Nguyen $\mathrm{T}$, Marilena L and Alexander $\mathrm{M}$. Toxicological considerations of clinically applicable nanoparticles. Nano Today 2011; 6:585-607.

6. Czarnobaj $\mathrm{K}$ and Lukasiak J. In vitro release of cisplatin from sol-gel processed organically modified silica xerogels. J Mater Sci Mater Med 2007; 18: 2041-2044.

7. Ju-Nam, Y. and Lead, J. Manufactured nanoparticles: An overview of their chemistry; interactions and potential environmental implications. Sci. Total Environ 2008;400:396-414.

8. Shi J., Votruba A. R., Farokhzad O. C, and Langer R. Nanotechnology in Drug Delivery and Tissue Engineering: From Discovery to Applications. Nano Lett 2013;10:3223-3230

9. Halas NJ. Nanoscience under glass: the versatile chemistry of silica nanostructures. ACS Nano 2008; 2:179-183.

10. Wang W, Gu B, Liang L and Hamilton W. Fabrication of near infrared photonic crystals using highly monodispersed sub-micrometer $\mathrm{SiO} 2$ spheres. JPCB 2003; 107:12113-12117.

11. Hoet PHM, Brueske-Hohlfeld I and Salata O. Nanoparticles known and unknown health risks. J Nanotoxicol 2004; 2:1-2.

12. Bharali DJ, Klejbor I and Stachowiak EK. Organically modified silica nanoparticles a non viral vector for in vivo gene delivery and expression in the brain. PNAS 2005; 102:11539-11544.

13. Roy I, Ohulchanskyy T, Bharali D, Pudavar H, Mistretta R, Kaur N and Prasad P. Optical tracking of organically modified silica nanoparticles as DNA carriers: a non viral, nanomedicine approach for gene delivery. PNAS 2005; 102:279-284.

14. Sun $\mathrm{H}$ and $\mathrm{Zu} \mathrm{Y}$. Aptamers and their applications in nanomedicine. Small 2015; 20:2352-2364. 
15. Canesi L, Ciacci C, Betti M, Fabbri R, Canonico B, Fantinati A, Marcomini A and Poiana G. Immunotoxicity of carbon black nanoparticles to blue mussel hemocytes. Environ Int 2008; 34:1114.

16. Schrand AM, Rahman MF, Hussain SM, Schlager JJ, Smith DA and Syed AF. Metal - based nonoparticles and their toxicity assessment. WIREs Nanomed Nanobiotech 2010; 2: 544- 568.

17. Ross HM, Pawlina W. "Histology A Text and Atlas with correlated cell and molecular biology". $6^{\text {th }}$ ed, Philadelphia, Baltimore, New York, London, Buenos Aires, Hong Kong, Sydney, Tokyo. Lippincott Williams \& Wilkins. 2016; PP: 626-639.

18. Lee S, Yun HS and Kim S H. The comparative effects of mesoporous silica nanoparticles and colloidal silica on inflammation and apoptosis. Biomaterials 2011; 32:9434-9443.

19. Nishimori $\mathrm{H}$, Kondoh $\mathrm{M}$, Isoda $\mathrm{K}$, Tsunoda $\mathrm{S}$, Tsutsumi Y and Yagi KA. Silica nanoparticles as hepatotoxicants. Eur J Pharm Biopharm 2009; $72: 496-501$

20. Survarna SK, Layton C, Bancroft JD. Bancroft's theory and practice of histological techniques, 7th edition, Churchill Livingstone, UK, El Sevier 2013; pp: 408.

21. Bozzola J and Russel L. "Electron microscopy. Principles and techniques for biologists". 2nd ed. Boston, Toronto, London, Singapore, 1999; PP: 148201.

22. Xie G, Sun J, Zhong G, Shi L and Zhang D. Biodistribution and toxicity of intravenously administered silica nanoparticles in mice. Arch Toxicol 2010; 84:183-190.

23. Sun L, Li Y, Liu X, Jin M, Zhang L, Du Z, Guo C, Huang $\mathrm{P}$ and Sun Z. Cytotoxicity and mitochondrial damage caused by silica nanoparticles. Toxicol in Vitro 2011; 25:1619-1629.

24. Kumar V, Abbas A and Aster J. Robbins Basic Pathology. Ninth edition, Philadelphia: Elsevier Inc. 2013; 117-120.

25. Begriche K, Massart J, Robin M, Borgne-Sanchez $A$ and Fromenty B. Drug-induced toxicity on mitochondria and lipid metabolism: mechanistic diversity and deleterious consequences for the liver. J Hepatol 2011; 54:773-794.

26. Gomes L, Benedetto G and Scorrano L. During autophagy mitochondria elongate, are spared from degradation and sustain cell viability. Nat Cell Biol 2011; 13:589-598.

27. Esposti D, Hamelin J, Bosselut N, El Saffroy R, Sebagh M, Pommier A, Martel C and Lemoine A. Mitochondrial roles and cytoprotection in chronic liver injury. Biochemistry Research International 2012; 2012:1-11

28. Mesnage R, Renney G, Séralini G, Ward M and Antoniou MN. Multiomics reveal non-alcoholic fatty liver disease in rats following chronic exposure to an ultra-low dose of Roundup herbicide. Scientific Reports 2017; 7: 28-39.

29. Motoyama H, Komiya T, Thuy T, Tamori A, Enomoto M, Morikawa H, Iwai S, Kobayashi S, Fujii H, Hagihara A, Kawamura E, Murakami Y, Yoshizato $\mathrm{K}$ and Kawada N. Cytoglobin is expressed in hepatic stellate cells, but not in myofibroblasts, in normal and fibrotic human liver. Lab Invest 2014; 94:192-207.

30. Taura K, Iwaisko K, Hatano E and Uemoto S. Contaversies over the epithelial to mesenchymal transition in liver fibrosis. J Clin Med 2016; 5:1-9.

31. Li J, Ghazwani M, Zhang Y, Lu J, LI J and Fan J. miR122 regulates collagen production via targeting hepatic stellate cells and suppressing P4HA1 expression. J Hepatol 2013; 58: 522-528.

32. Mederacke I, Hsu C, Troeger J, Huebener P, Mu X, Dapito D, Pradere J and Schwabe F. Fate-tracing reveals hepatic stellate cells as dominant contributors to liver fibrosis independent of its etiology. Nat Commun 2013; 4: 2823.

33. Higashiyama $\mathrm{R}$, Moro $\mathrm{T}$, Nakao $\mathrm{S}$, Mikami $\mathrm{K}$, Fukumitsu Hand Ueda Y. Negligible contribution of bone marrow-derived cells to collagen production during hepatic fibrogenesis in mice. Gastroenterol 2009; 137:1459-1466.

34. Iwaisako K, Jiang C, Zhang M, Cong M, Morris T, Park T, Liu X, Xu J, Wang P, Paik Y, Meng F, Asagiri M, Murray L, Hofmann A, Iida T, Glass C, Brenner $\mathrm{D}$ and Kisselevac T. Origin of myofibroblasts in the fibrotic liver in mice. Proc Natl Acad Sci U S A 2014; 32: 3297-3305.

35. Figiel S, Vasseur C, Bruyere F, Rozet F, Maheo K and Fromont G. Clinical significance of epithelialmesenchymal transition markers in prostate cancer. Hum Pathol 2017;61:26-32

36. Kmieć Z. Cooperation of liver cells in health and disease. Adv Anat Embryol Cell Biol 2001; 161:1-151.

37. Nakatani K, Kaneda K and Nakajima S. Pit cells as liver-associated natural killer cells. Morphology and function. Med Electron Microsc 2004; 37:29-36. 
38. Peng H, Wisse E, and Tian Z. Liver natural killer cells: subsets and roles in liver immunity. Cell Mol Immunol 2016;13:328-336.

39. Radaeva S, Sun R, Jaruga B, Nguyen T, Tian Z and Gao B. Natural killer cells ameliorate liver fibrosis by killing activated stellate cells in NKG2D-dependent and tumor necrosis factor-related apoptosis-inducing ligand-dependent manners. Gastroenterol 2006; 130:435-452.

40. Tosello-Trrampont A, Surette F, Ewald S and Yahn Y. Immunoregulatory role of $\mathrm{NK}$ cells in tissue inflammation and regeneration. Front Immunol 2017; 8: $301-311$.

41. Shi J, Zhao J, Zhang X, Cheng Y, Hu J, Li Y, Zhao X, Shang Q, Sun Y, Tu B, Shi L, Gao B, and Zhang
Z. Activated hepatic stellate cells impair NK cell anti-fibrosis capacity through a TGF- $\beta$-dependent emperipolesis in HBV cirrhotic patients. Sci Rep 2017; 7:44-50.

42. Vessey CJ, de la Hall PM. Hepatic stem cells; a review. Pathology 2001; 33:130-141.

43. Libbrecht L, Cassiman D, Desmet V and Roskams T. The correlation between portal myofibroblasts and development of intrahepatic bile ducts and arterial branches in human liver. Liver 2002; 22:252-258.

44. Kholodenko I and Yarygin K. Cellular mechanisms of liver regeneration and cell-based therapies of liver diseases. Biomed Res Int 2017; 2017: 1-17. 


\section{الملخص العربى}

\section{تاثير جزيئات اكسيا السيليكا متناهيه الصغز على الكبا فى ذكر الجرذ الابيض البالغ. دراسه بالميكروسكوب الضوئى والالكترونى}

\section{شيماء فطين، نقزت فريد عبد السلام، نيقين بهاء، ولاء باهر}

\section{قسم الههيتولوجيا وبيولوجيا الخلية، كلية الطب، جامعة عين شمس}

المقدمة: جسيمات أكسيد السيليكا متتاهيه الصغر لها دور اساسي بسبب خصائصها الجو هرية. فحجمها يتميز بمدى و اسع (من ه إلى . . . ( نانومنز)، كما ان لها خصائص بصرية فريدة من نوعها، و مساحة محددة عالية، و كثافة منخفضة، و قدرة على الامتز از، و التغليف، و التلاعم الحيوي. وقد أدت كل هذه المميزات إلى استخدامها على نطاق و اسع في التطبيقات الطبية الحيوية مثلا كداعم للمو اد الكيميائية الحافزة، وكحامل للادوية، وتوصيل الجينات. و لكن هناك قله في معرفة تأثثرها السمي الخلوي خاصة مع توزيعها الحيوي على نطاق واسع في مختلف الأعضاء. الهُف من البحث: تقييم تأثير جرعات مختلفة ومدد حقن مختلفة في الوريد من جسيمات أكسيد السيليكا متتاهيه الصغر على تركيب الأنسجة الكبدية في ذكور الجرذان البيضاء البالغين. المادة والطرق : تم استخدام الطرق أربعين من ذكور الجرذان البيضاء البالغة و تم تقسيمهم عشوائيا إلى ثلاث مجموعات. المجمو عة الأولى؛ استخدمت كمجمو عة ضابطة، المجموعة الثانية؛ تم حقن • ( مج من جسيمات أكسيد السيليكا متناهيه الصغر لكل كيلوجر ام من وزن الجسم لمدة أسبو عين و لمدة أربعة أسابيع و المجمو عة الثالثة؛ تم حقن ـامج من جسيمات أكسيد السيليكا متتاهيه الصغر لكل كيلوجر ام من وزن الجسم لمدة أسبو عين ولمدة أربعة أسابيع. أعطيت جميع الأدوية عن طريق الحقن في وريد الذيل. في نهاية التجربة تم استخر اج الكبد فى جميع المجمو عات ومعالجته و اعداده لدر اسات نسيجية، هيستو كيميائية مناعية

$$
\text { وتركيبيه دقيقه. كما أجريت قياسات شكلية وتحليل إحصائي. }
$$

النتائج: لم يتسبب حقن جيمات أكسيد السيليكا متتاهيه الصغر بأي جر عه او مده في تغيير النظام التركيبي لفصيات الكبد. و لكن تسببت في في حدوث تفاعلات التهابية كبدية متكورة مصاحبة لتليف محدود. و الذي كان اكثر وضوحا كلماز ادت جر عات جسيمات أكسيد السيليكا متتاهيه الصغر و مدد اعطائها. الاستنتاج و التوصيات: تستطيع جسيمات أكسيد السيليكا متتاهيه الصغر التأثنير على الكبد حتى في الجرعات القليلة. و زاد هذ التأثير مع زيادة الجرعة ومدة الاعطاء. و يجب عمل أبحاث اكثر لتوضيح تفاعل خلايا الكبد مع الخلايا الأخرى الكبديه الغير 